\title{
The Subsidized Green Revolution: The Impact of Public Incentives on the Automotive Industry to Promote Alternative Fuel Vehicles (AFVs) in the Period from 2010 to 2018
}

\author{
Patrick Reimers (D)
}

check for updates

Citation: Reimers, P. The Subsidized Green Revolution: The Impact of Public Incentives on the Automotive Industry to Promote Alternative Fuel Vehicles (AFVs) in the Period from 2010 to 2018. Energies 2021, 14, 5765. https://doi.org/10.3390/en14185765

Academic Editor: Mario Marchesoni

Received: 18 July 2021

Accepted: 7 September 2021

Published: 13 September 2021

Publisher's Note: MDPI stays neutral with regard to jurisdictional claims in published maps and institutional affiliations.

Copyright: (C) 2021 by the author. Licensee MDPI, Basel, Switzerland. This article is an open access article distributed under the terms and conditions of the Creative Commons Attribution (CC BY) license (https:// creativecommons.org/licenses/by/ $4.0 /)$.
Department of Applied Economics, History, Economic Institutions \& Moral Philosophy, Faculty of Social and Legal Sciences, URJC King Juan Carlos University, 28033 Madrid, Spain; p.reimers.2016@alumnos.urjc.es

\begin{abstract}
Throughout decades, conflicts related to the access and usage of various energy sources have caused political tensions between nations and confederations of states. Thus, partially to decrease the dependence on fossil fuels, a thorough transition towards renewable energies has been promoted by several regional and national governments as well as by multinational institutions such as the European Union. In this context, the automotive industry has particularly been held responsible for the production of negative externalities, such as global greenhouse gas emissions (GHG emissions), noise and air pollution. To a notable extent, these externalities were caused by vehicles running on fossil fuels such as petroleum products, including gasoline, diesel fuel and fuel oil. Accordingly, it is often argued that replacing vehicles run by internal combustion engines (ICEs) with so-called alternative fuel vehicles (AFVs), particularly with plug-in electric vehicles (PEVs), is crucial to increase the sustainability of the transport sector. Moreover, several EU-member states aim to reduce the vehicle-related petrol and diesel demand to decrease their dependence on foreign energy sources. However, one must consider that there are important economic costs related to such a transition process. This paper evaluates the short-term and long-term effects of fiscal policies on the European automotive market in the period from 2010 to 2018, focusing on the impact of mentioned public incentives for AFVs. This public interventionism will be critically evaluated to examine the effectiveness of government incentives in promoting AFVs, particularly for plug-in electric vehicles (PEVs). The author argues that the rather positive sales evolution of AFVs was not caused by corresponding actual customer demand but mainly by governmental policies in an increasingly interventionist market. He acknowledges that the growing variety of available PEV models, the increasing driving range of electric vehicles, as well as their decreasing production costs due to economies of scale, have helped PEVs to become more competitive. However, the concern should be raised that mentioned public interventionism is unsustainable from a macroeconomic perspective, possibly leading to significant market distortion and a new artificial market bubble. The narrowed focus on battery electric vehicles prevents the market from further elaborating on other potentially more sustainable technologies. Moreover, from a geostrategic perspective, the transition of the European automotive industry towards electrification is likely to reduce the EU's dependency on imported fossil fuels but enables several non-European automotive brands to conquer a significant market with their new competitive plug-in electric vehicle technologies.
\end{abstract}

Keywords: automotive industry; public incentives; fiscal policies; carbon dependability; green energy reliability; public interventions; alternative fuel vehicles; battery electric vehicles; energy costs

\section{Introduction}

Access to energy-providing resources has been of geopolitical relevance throughout many decades. Moreover, the impact of the transport sector on climate change and energyrelated greenhouse gas (GHG) emissions has become a major aspect of political discussion throughout the past years [1]. Vehicles run by fossil fuels such as petroleum products such as gasoline, diesel fuel or fuel oil are not only criticized for mentioned global GHG 
emissions but also for causing noise and local air pollution, hampering people's health, particularly in urban environments. Moreover, governments of several EU-member states criticized the car-related petrol and diesel demand for having created a strong dependence on foreign energy sources, depending on providers from non-EU and non-NATO countries [2].

Primarily based on these reasons, national and local governments in Europe, but also in other parts of the world, have adopted a wide range of measures to increase the use of alternative fuel vehicles (herein abbreviated by "AFVs"). Already, in 2010, a total of $16 \mathrm{EU}$ member states had implemented a tax and/or purchase incentive related to vehicle engine fuel types. Particularly throughout the past decade, a thorough transition towards the usage and production of renewable energies was incentivized by public and multinational institutions [3].

In the EU, the patchwork of initiatives, legislation and incentives on a local and national level has been changing significantly within the 21st century and is expected to continue doing so in the near future [4]. Already, by 2012, countries such as Denmark, France, Germany, Ireland, the Netherlands, Portugal and the UK had implemented their own initiatives [5]. Meanwhile, Norway, which was seen as the benchmark in regard to AFV incentives, offered a combination of purchase tax exemption and local user benefits [6]. Thus, such public incentives and other public interventions related to the currently seen "green mobility transition" have caused important economic costs [4].

Since the end of World War II, the European automotive industry has generally shown a stable growth rate, only significantly hampered by the effects of the so-called " 1973 oil crisis", the latest financial crisis ("subprime crisis") in the period from 2007 to 2009 as well as by the effects of the COVID-19 disease spread and consequent "economic lockdowns" in 2020 and 2021. As a consequence of the economic bust in 2008 and to "stabilize the economy", several monetary policies (such as "quantitative easing") and fiscal policies (including scrappage campaigns and other public incentives) were implemented by central banks and governments, ultimately causing further market distortions and unsustainable economic effects such as prolonged periods of low interest rates, financial volatility and a misallocation of resources [7]. The popular explanation among politicians and journalists is that laissez-faire-often also disrespectfully referred to as "neo-liberal"—politics had deregulated the financial markets, which ultimately led to the financial crash $[8,9]$. While also considering the opposite hypothesis, that national governments and other institutions are the actual originators of the mentioned crisis, the author "tries to connect the dots", arguing that such interventionist policies, implemented with the aim to "stimulate investments and consumption", ultimately lead to further unsustainable distortions in the automotive industry $[7,10,11]$. Accordingly, this paper evaluates whether the recent sales increase in alternative fuel vehicles (AFVs) was mainly caused by the corresponding public incentives. In the affirmative case, the author considers that such market distortion will likely lead to a harmful misallocation of resources with another unsustainable market bubble.

This paper only focuses on vehicles that use one or more electric motors or traction motors for propulsion, including hybrid vehicles (H-EV). Thus, vehicles run on alcohols (such as ethanol and methanol) or methane (including natural gas and biogas), as well as biodiesel and synthetic fuels, are herein not considered as AFVs. In the recent specialized literature, the term "alternative fuel vehicles" (AFVs) generally refers to "Plug-in electric vehicles", abbreviated by "PEVs". A "PEV" is any vehicle that can be recharged via an external source of electricity, e.g., wall sockets. Thus, the abbreviation "PEV" can currently be seen as an umbrella term for electrified vehicles, which includes all-electric, or battery electric vehicles (B-EVs), as well as plug-in hybrid vehicles (PH-EVs). In addition, hybrid vehicles (H-EVs) are also included in this analysis on AFVs, as this technology must be seen as the "stepping stone" for alternative fuel concepts, which has paved the way for plug-in hybrid electric (PH-EVs) vehicles and battery electric vehicles (B-EVs). Thus, whereas hybrid vehicles ("H-EVs") are herein considered AFVs, they do not belong to the group of "PEVs". 
To limit our research to a crucial period of time, this paper focuses on analyzing the timeframe from 2010 to 2018. In this perspective, the year 2010 is seen as the beginning of the post-financial crisis era (which was shaped by the filing for bankruptcy of Lehman Brothers Holdings Inc, General Motors filing for government-backed Chapter 11 reorganization, as well as by the different automotive scrappage campaigns launched by various governments to "protect the automotive sector and its employees" [12,13]. The year 2018 can be seen as a crucial tipping-point in regard to the mass-market breakthrough of AFVs, as according to the Norwegian Road Traffic Information (OFV), more than 50\% of all new passenger car sales in Norway, which occurred in the second half of 2018, were "plug-in electric vehicles" (B-EVs + PH-EVs). Thus, 2018 must be seen as the year in which alternative fuel vehicles became "mainstream" products in at least one country belonging to the European Free Trade Association (EFTA). Accordingly, the automotive sector has seen significant changes within the past decade, strongly influenced by public incentives for alternative fuel vehicles and other public interventions.

Several studies indicate that there are crucial environmental, consumer fuel-saving and macroeconomic benefits [14] associated with alternative fuel vehicles, which are said to exceed the costs of electric vehicle incentives [15]. Moreover, it is expected that throughout the next decades, public incentives for AFVs can be reduced due to the ongoing optimization of these vehicle technologies, not only in regard to their production costs but also regarding their driving range, which will naturally increase their competitiveness [16]. In addition, the author argues that it is likely that the recent "positive" public interventions to support AFV sales (e.g., tax exemptions for AFVs) will simply be replaced by "negative interventions", such as further regulations and taxes on ICE vehicles, or even their entire ban from European roads. By doing so, public entities could further steer the transition towards the "electric revolution" without needing significant public budgets for long-term public AFV incentives. Meanwhile, public subsidies and tax reductions implemented for electric vehicles in several European markets were substantial throughout recent years [1,17]. Governments have increased this market growth through a combination of financial incentives, other incentives such as parking and lane access, as well as by supporting charging infrastructure, training/education and outreach activities [16]. Consequently, in particular, in Norway and the Netherlands, incentives have helped to significantly reduce the total vehicle costs of PEVs [18]. However, PEVs still face relevant barriers to adoption; barriers that are common to most new technologies include the lack of knowledge by potential adopters, a low consumer risk tolerance $[19,20]$ and high initial production costs [21].

It is also key for this research to look at the importance of a free price system, crucial to properly allocate resources since, on the contrary, governmental interventions on pricing via taxes and subsidies lead to a hampering market distortion [22,23].

The "electric car revolution" was mainly initiated by the launch of models such as Opel Ampera /Chevrolet Volt, the Nissan Leaf and Tesla's Model S [24]. Previous research related to AFVs has thoroughly analyzed the impact of fiscal incentives for AFV users [2,5,6,15] as well as of regulations directly affecting manufacturers [25]. Throughout the past years, public entities on the EU, national and municipal levels have tried to promote alternative fuel vehicle technologies with different forms of fiscal and legal support. Meanwhile, a wide range of incentives and promotion actions exist which different national and even regional governments have adopted to increase the attractiveness of AFVs. These incentives have clearly increased the awareness of AFVs. This paper focuses on the four most relevant alternative fuel technologies within the period from 2010 to 2018, which are hybrid (H-EV) and plug-in hybrid (PH-EV) as well as "full-electric" / battery electric (B-EV) and fuel cell (FC-EV) engines. As indicated, hybrid vehicles (H-EVs) are also included in this analysis on AFVs, as this technology must be seen as the "door-opener" for plug-in hybrid electric (PH-EVs) vehicles and battery electric vehicles (B-EVs).

In the early 2020's, Europe is still in the adoption phase of AFVs with a relatively low market share in most markets [1,4]. From a different perspective, one can positively high- 
light that particularly in certain north-western European countries, such as the Netherlands and Norway, sales volumes of AFVs have constantly been growing to advanced levels $[5,6]$. Interest in alternative fuel technologies also increased due to the so-called "(Volkswagen) diesel emission scandal" and the continuous approach by governments to reduce fine particulate and nitrogen oxide (NOx) emissions [6]. It should critically be evaluated if public incentives could, in any case, be justified from an economic perspective or whether any form of public incentives is unsustainable, leading to harmful market distortion. To detect the actual price competitiveness of PEVs with traditional internal combustion engine (ICEs) vehicles, independently from any public support, "total cost of ownership" comparisons (TCO comparisons) of ICEs versus PEVs are considered, including all costs related to the vehicle ownership and usages, such as fuel costs and insurance costs, as well as repair, maintenance and service costs (RMS costs) $[2,5,17]$. The author argued that in order to assure the long-term stability of the market, sustainability needs to be assured, and product distribution must primarily be based on actual customer demand, not on public incentives. The hypothesis is raised that in case such sustainability is not provided, mentioned fiscal interventionism to artificially boost vehicle sales will further distort the market, causing a new form of "bubble" that could ultimately lead to another severe crisis in the automotive sector.

\section{Literature Review}

In his book "1984", Orwell ironically stated: "The best books ... are those that tell you what you know already." [26]. Thus, to provide a holistic overview of the latest research on the analyzed topics, a broad and intense literature review is seen as crucial. In regard to alternative fuel vehicles, several empirical studies on the sales evolution of AFVs and on consumer preferences for AFVs were published over the last decades [2,5,6,15,17-19]. Even detailed comparisons of the individual public incentive models can be found. In 2003, for example, Canes finalized a study comparing the total lifecycle costs of equivalent hybrid and gasoline models of that time and detected that lifecycle costs for hybrid vehicles clearly exceeded those for equivalent non-hybrid vehicles at the corresponding fuel prices at the time of analyses [27]. On the one hand, the author focuses on the recognized academic secondary literature related to macroeconomics, monetary policies and fiscal policies. Thus, a wide variety of books from different schools of thought, such as the Austrian School of economics, Keynesianism, monetarism, public choice economics, new institutionalist economics and the economics of governance, including the Bloomington school, were studied. On the other hand, this research also used academic papers related to the automotive industry, with special emphasis on the so-called "scrappage campaigns" in the early 21st century [11-13] and public incentives for alternative fuel vehicles $[5,6,18]$. The mentioned literature helped to properly evaluate the main research objectives, which are to evaluate the impact and effectiveness of public incentives for AFVs on the vehicle sales evolution in Europe and to illustrate the sustainability and market competitiveness of AFVs without public incentives [1,4,5,18,24,27].

According to Axsen et al., the main constraint to the commercialization of "Plug-in electric vehicles" (PEVs) was the limited energy storage, while the evolution of battery technology was limited by the trade-off between power, energy, longevity, cost and safety [28]. Several studies confirm that governments have incentivized this market growth through a combination of financial incentives, other incentives such as parking and lane access, as well as by supporting charging infrastructure [29]. Previous research related to AFVs thoroughly analyzed the impact of fiscal incentives for AFVs users $[2,18,30,31]$ and of regulations directly affecting manufacturers $[32,33]$. In particular, in Norway and the Netherlands, public incentives were sufficiently high to increase the cost competitiveness of PEVs, for which these markets were analyzed in particular [18,34,35]. Several other academic papers on the competitiveness of AFV technologies were also reviewed, particularly focusing on the most challenging aspects for EVs, such as the limited maximum driving speed, relatively long recharging times, high initial purchase prices [36], still relatively 
low driving ranges [28] and a limited network of recharging stations [37]. The vehicle's driving range and the need to recharge PEVs are generally seen as crucial factors, but only a very few studies actually distinguished between "longer and shorter" recharging times. Reference is also made to authors who strongly question any economic benefits of the recent incentives for AFVs [4,38]. The author of this paper also considered aspects of customer behavior modeling, referring to corresponding models such as the "diffusion of innovations model", the "theory of planned behaviour", as well as the "willingness to consider concept" $[17,39-41]$.

\section{Methodology and Data Collection}

This research considers diverse viewpoints and research approaches, combining the analysis of quantitative, empiric data with the usage of economic theory. The author's approach aims at evaluating whether there are "general, axiomatic effects", caused by mentioned public interventionism. Thus, while recognizing regional particularities, the author of this paper elaborates on the feasibility of defining categorical conclusions. Triangulation is used to gain a thorough understanding from different perspectives of the investigated phenomenon. As a primary methodology, cross-sectional time-series analysis of AFV registration statistics over time from different European countries is used. These crosssectional analyses were used to detect potential causalities between vehicle registrations and public supports for AFVs. Accordingly, primary market data from ACEA and other institutions and well-known private data providers were used [3] to test the relationship between AFV adoption and the corresponding public policy variables. One significant difficulty in analyzing AFV adoption by using time series data is to truly define the proper correlation between the specific independent ("public incentives") and the dependent variable ("customer demand"), as the status and impact of several intervening, moderating and control variables has also significantly changed over the analyzed period. For example, public incentives might have developed in line with other crucial changes such as an optimization of the recharging network, the extension of the vehicles' driving range, and a general consciousness for environmental issues. Different tools of quantitative research are used, using large sets of data to show a proper and comprehensive "big picture" reaching generalizable and reliable conclusions. However, this paper is not meant to be a pure "case study" empirically evaluating a limited period of time in history. The author recognizes the limitations of empiricism, also acknowledging that pure induction does not allow us to define any general valid conclusions $[10,23,42]$. Thus, it is crucial to properly distinguish between theory and history, applying methodological dualism. Accordingly, the author acknowledges the crucial differences between socio-economic sciences on the one hand and natural sciences on the other hand [42]. It is argued that economic prediction cannot disclose precise information on the concrete quantitative future relations concerned, for which truly scientific, economic forecasts can only be qualitative. In this context, reference is made to the theory and methodology used in several relevant papers, which indicated the economic harm caused by market-distorting public interventionism [7,10-13]. This paper's aim is to enrich economic theory with a thorough analysis and new findings on the defined research objective. Thus, apart from recent academic papers, different schools of thought on economic theory are also considered, particularly acknowledging the concepts of the Austrian School of economics, public choice economics and new institutionalist economics.

\section{Analysis of the AFV Market Evolution}

Throughout the first decade of the 21st century, Western automotive markets were mainly shaped by those European and US-American automotive manufacturing companies that had already been in the market for several decades. These so-called original equipment manufacturers ("OEMs") focused on the production of traditional internal combustion engine vehicles (ICE vehicles), mostly operating in a low margin business, with complex supply chains while pushing sales volumes, trying to assure economies of scale. Auto- 
motive OEMs focused on constantly updating the vehicles' design as well as improving engine powertrains in regard to performance and consumption, but fierce competition and the mentioned low margins have kept most OEMs from focusing on courageous long-term planning with truly revolutionary product developments [43]. Then, in 2012, Tesla Motors, Inc. introduced its Model S. The US-American company Tesla, founded in 2003, focused on the production and distribution of electric vehicles (B-EVs) with the declared purpose to support the transition from a mine-and-burn hydrocarbon economy towards a solar electric economy. At that time, only a few automotive OEMs, such as Nissan, Renault, Mitsubishi and General Motors, had started the mass production and selling of battery electric vehicles.

As indicated, in recent years, the impact of the transport sector on climate change and energy-related greenhouse gas (GHG) emissions became a major aspect of political discussion $[1,28,43]$. Accordingly, vehicles run by fossil fuels such as petroleum products, i.e., gasoline, diesel fuel or fuel oil, have increasingly been criticized, not only for global GHG emissions but also for causing noise and local air pollution, hampering people's health, in particular in urban environments [43,44]. Moreover, in particular, EU-member states criticize the car-related petrol and diesel demand for having created a strong dependence on foreign energy sources, depending on providers from non-EU and non-NATO countries [2].

Based on these reasons, national and local governments in Europe, and also in other parts of the world, adopted a wide range of measures to increase the use of alternative fuel vehicles [45]. From a neoclassical perspective, market inefficiency is an indication of "market failure" for which government intervention appears to be necessary to "readjust" the market. Regarding externalities, the neoclassical notion of market externalities elaborates on the concept of costs and benefits to society as a whole as well as on the expanded concept of "social efficiency" [23].

Alternative fuel vehicles (AFVs) are vehicles that can be fuelled either partially or entirely by alternatives to fossil gasoline and diesel. The market of alternative fuel vehicles is comprised of battery electric vehicles (B-EVs), plug-in hybrid electric vehicles (PH-EVs) and hybrid electric vehicles (HEVs), as well as fuel-cell electric vehicles (FC-EVs). Thus, the author takes a closer look at these four main alternative fuel technologies, which have been most successful in Europe throughout the past years. B-EVs do not require gasoline at any point during their operation, relying purely upon electric battery power. PH-EVs, just like B-EVs, use a lithium-ion battery and run on an electric engine [28]. However, PH-EVs will switch to the gasoline engine each time their electric battery runs low. In this research, these technologies are mostly combined under the term "alternative fuel vehicles" (AFVs) in comparison to the traditional internal combustion engine vehicles (ICEs). As indicated in several statistics, PH-EVs and B-EV are often combined and shown as PEVs (plug-in electric vehicles). Thus, particularly when looking at recent developments, reference is often made to the mentioned term "plug-in electric vehicle" ("PEVs").

Accordingly, at the beginning of the second decade of the 21st century, with the launches of a large variety of battery electric vehicles (B-EVs) and plug-in hybrid electric vehicles (PH-EVs), the situation has significantly changed throughout the past 10 years. While by now, all major Western automotive OEMs have launched models with the corresponding engine AFV technologies, and several new (mainly Chinese) automotive companies are also entering the European market with competitive PEV models [46].

Several aspects, such as vehicle prices, fuel prices and maintenance costs, as well as circulation, registration and luxury taxes for petrol and diesel vehicles, or alternatively sales tax waivers and income tax credits for alternative fuel vehicles (AFVs), can have a crucial impact on the success or disappearance of entire fuel type technologies $[43,47]$. The desire to reduce one's own carbon footprint by using low-emission vehicles, and the often-provided usage benefits of AFVs, e.g., preferential urban parking space or the permission to use the bus and taxi lanes during rush hours, were relevant AFV purchase reasons [24]. However, one significant difficulty in analyzing the effectiveness of AFV adoption by using time series 
data is to truly define the proper correlation between the specific independent ("public incentives") and the dependent variable ("customer demand"), as the status and impact of several intervening, moderating and control variables has changed throughout the evaluated period of time. For example, public incentives for AFVs might have developed in line with other crucial changes such as an optimization of the recharging network, the optimization of the vehicles' driving range and a general consciousness for environmental issues [48].

\subsection{Environmental Protection and the Rise of Public Incentives for AFVs}

By the year 2007, more than $88 \%$ of all analyzed Spanish companies within the automotive industry had already defined their own internal quantitative objectives related to "environmental protection" [49]. In the case of larger analyzed corporates (with more than 250 employees), even $96.6 \%$ had already defined such objectives. By the end of $2007,76 \%$ of these companies had already implemented an internal corporate strategy on environmental protection, and even $81.3 \%$ had implemented a related certified management system such as ISO 14001 [49]. These interesting numbers indicate that, far before significant public incentives for AFVs were implemented, entrepreneurs and managers within the automotive sector had already recognized the need to consider environmental concerns in the definition of future corporate priorities and strategies. The author intends to evaluate whether, as soon as AFV technologies had become a serious competitive alternative to ICEs for consumers, the market would have embraced such new technologies without any public interventionism.

Historically, public support for OEMs by providing public incentives (such as the former public scrappage campaigns and bailout packages) have differed between the individual countries, but the main purpose of these public interventions has generally been to "stabilize the economy while protecting workers" [12,13]. The author argues that in order to assure the long-term stability of the market, sustainability needs to be assured, and product distribution must primarily be based on actual customer demand, not on public incentives. Accordingly, this analysis emphasized the long-term importance of free prices [50], crucial to properly allocate resources, since on the contrary, (long-term) governmental interventions on pricing via taxes and subsidies lead to malinvestments and market distortions [51], which could ultimately cause a new crisis of the automotive sector [1,4]. Throughout the past years, public entities on the EU, national and municipal levels have tried to promote alternative fuel vehicle (herein abbreviated by "AFVs") technologies with different forms of fiscal and legal support. Whereas previous public incentives were often justified with the official aim to "protect workers from unemployment", the recent incentives for AFVs are being justified with the aim to "reduce air pollution, $\mathrm{CO}_{2}$ emissions and global warming". These incentives have clearly increased the awareness of AFVs and have overall led to a notable growth of the AFVs' sales evolution [2,4,17]. By December 2019, all EFTA member states and the UK combined accounted for $25 \%$ of all PEVs globally in use. Whereas in 2016, PEVs only had a market share of $1.3 \%$ of all new car registrations in the EFTA+UK region, the share rose to $3.6 \%$ in 2019 [52]. Figure 1 illustrates the notable increase in annual PEV sales in Europe (EFTA region and the UK) in the time period from 2011 to 2019.

The above chart shows the annual increase in vehicle registrations with a "full-electric" engine (B-EVs) or a plug-in hybrid technology (PH-EVs) within the EFTA region (including the UK). The public support for "AFVs" has differed between individual countries and often even between municipalities: meanwhile, the most common justifications for the increase in public incentives are to minimize the dependency on fossil fuels as well as to decrease greenhouse gas (GHG) emissions. Particularly in populated cities where mobility activities significantly contribute to generating negative externalities, the optimization of environmental sustainability in transport solutions requires new technologies, such as optimization of vehicle engines. Thus, the diffusion of AFVs (mainly PEVs) shall play a major role in reducing the environmental pollution. Around the world, policy-makers have intensified the implementation of new strategies in order to increase the market 
share of PEVs $[28,53]$. Several automotive experts define the currently available PEV technologies as superior to ICE from an environmental perspective and consider them as a key aspect towards the transition to a truly sustainable transportation system. Several frameworks and theoretical models were used to come to concrete conclusions. Up until the late 2010s, it was unclear whether PEVs would remain niche market products, only adopted by a small fraction of consumers, or whether they could truly become a mass product. Several papers written on AFV evaluated the influence of sociodemographic factors [54] and the relevance of fuel consumption and tax incentives on the adoption decision [55]. In addition, several researchers looked into attitudinal psychological factors such as moral values and environmental awareness [24], while others primarily emphasized the required recharging infrastructure [56]. Most of the mentioned literature shows that apart from the driving range and the actual vehicle costs, the public charging infrastructure has also been an important factor, although the detailed causalities cannot be precisely quantified. Thus, apart from the vehicle purchasing price, two main aspects considered by potential customers of B-EVs (and FC-EVs) were the status of the (public) recharging network as well as the actual recharging time for these vehicles $[28,56]$. Therefore, the continuous growth of B-EV sales will require further improvements in regard to battery technologies and a more extensive charging infrastructure. By the end of 2016, there were only 1403.public fast charging points in Germany, 523 fast chargers in Sweden, but already 1052 fast chargers in Norway [17]. Most consumers were reluctant to switch to B-EVs as recharging infrastructures were limited in many regions, for which they have consequently preferred conventional ICE technologies (or PH-EVs, if heavily subsidized). The question of how much public charging infrastructure is needed cannot be precisely answered, as this will also strongly differ between countries and by region. First of all, a regular charging option, such as home or workplace charging, is considered crucial for the success of PEV in the early market phase [56]. In this context, a significant difference can also be seen between most urban areas on the one hand and suburban and rural areas on the other hand. Consumers with their own garage or private parking space may rely on their personal charging infrastructure to ensure regular recharging, while most consumers living in innercity areas may mostly rely on public charging infrastructure or privately-run recharging stations. Despite the high amount of academic research papers written on the AFV sales evolution, they mostly came to rather unprecise and often contradicting findings on the concrete effectiveness of corresponding government incentives [28,44]. On the one hand, in several markets, such as the Netherlands, Scandinavia and several metropolitan areas such as London and Paris, AFVs (including hybrid vehicles) gained notable market shares throughout the second decade of the 21st century. On the other hand, and in particular, in most southern and eastern EU countries, the total number of AFVs in usage is still relatively low and rather disappointing. Thus, despite the proliferation of such incentive programs, their efficacy in actually leading to significant adoption of AFVs is unclear. Particularly PEVs are still struggling due to their high initial purchase prices, still relatively low driving ranges and a limited network of recharging stations [28,36]. These disadvantages restrained many consumers from adopting the mentioned new technologies [2].

To detect the actual price competitiveness of AFVs with traditional internal combustion engine vehicles, independently from any public support, one must consider "total cost of ownership" comparisons (TCO comparisons) of ICEs versus PEVs, including all costs related to the vehicle ownership and usage, such as fuel costs and insurance costs as well as repair, maintenance and service costs (RMS costs). Within this paper, the author raised the hypothesis that to assure a long-term and pan-European success of mentioned PEV technologies, sustainability needs to be assured, and product distribution must primarily be based on the actual customer demand, not on public incentives. Thus, it is argued that without strong public interventionism, the recently seen sales increase in AFVs/PEVs would not have been possible. A natural shift of the European mass market towards alternative fuel technologies could only occur if price competitiveness were given versus ICEs, which as of today is not the case. However, the seen significant public interventionism also led 
OEMs to tremendous investments into the optimization of AFV/PEV technologies [44]. It is argued by several automotive experts that, if significant public interventions are held up until the year 2024/2025, PEVs technologies can reach price competitiveness with ICEs [42], for which as of 2025, public interventions (and the corresponding public incentives for PEVs) could be reduced, whereas demand for PEVs could "naturally" continue growing. It is likely that the recent "positive" public interventions to support AFV sales (e.g., tax exemptions) will simply be replaced by "negative interventions", such as further regulations and taxes on ICE vehicles. By doing so, public entities can further steer the transition towards the "electric revolution" without needing significant public budgets for long-term public AFV incentives.

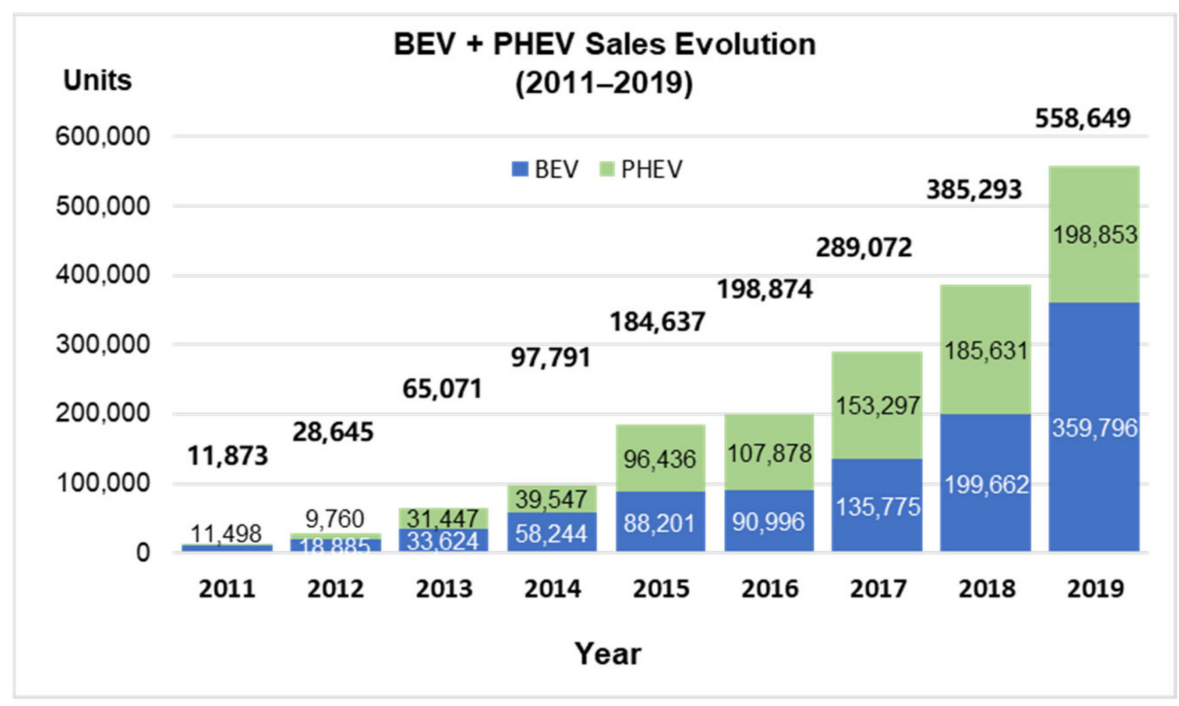

Figure 1. Annual sales of new PEVs in Europe (EFTA and UK) for passenger cars and light commercial vehicles (in units). Source: author's own elaboration based on data from IEA [52].

\subsection{Customer Behaviour and Its Impact on AFV Adaptation}

The author argues that properly understanding consumer behavior is crucial to design policies that could notably increase the uptake of new products and technologies. Innovation can be seen as the process of transforming opportunities into new ideas, putting them into practice [57]. The theory of planned behavior (TPB) by Ajzen links people's individual beliefs and behavior. Ajzen argues that attitude towards behavior, subjective norms, as well as perceived behavioral control together, shape an individual's behavior [58]. Sovacool and Hirsh (2009) stated that the majority of Western consumers while making choices, stick to "notions of traditions and familiarity" rather than look for new technologies [45].

One crucial aspect that has limited the success of AFVs is the uncertainty about the vehicles' total cost of ownership (TCO) as residual values (RVs) for these new technology vehicles could hardly be predicted. Thus, from a financial perspective, one major challenge to the success of AFVs, in particular for B-EVs and FC-EVs, is the uncertainty about the vehicles' actual total costs. Due to the significant progress in the AFV sector, including new engine technologies, new model launches and also a continuously high dependence on public interventionism, it was extremely challenging to forecast the residual value ("RV") of B-EVs, PH-EVs and FC-EVs. The total cost of ownership is also a key aspect in any corporate fleet tender, as it is ultimately not the new-car transaction price but its TCO, which defines the cost competitiveness of a vehicle model versus its competitors [59].

On the other hand, several analyses indicate that already by 2012, the development of social connotation of B-EV and PH-EV technologies had shown some impressive evolution: social connotative attributes, such as "environmental-friendly" and "high-tech", ideally combining the reduction in $\mathrm{CO}_{2}$ and NOx emissions with "connectivity \& infotainment", 
started to play a more significant role in the development of new vehicle models and engine technologies [60].

As indicated, customers need to see an actual benefit in using the new technology, and manufacturers need to detect a benefit in producing the new good [61]. However, other researchers state that the main constraint to the commercialization of PEVs was the limited energy storage, while the evolution of battery technology was limited by the trade-off between power, energy, longevity, cost and safety [28,62]. The durability of a battery depends on a number of factors such as the climate, the frequency of charging and the amount of energy involved in the charging process. Despite the general good intentions by most consumers to "help protecting the environment", fiscal incentives-if sufficiently high to offset cost differences between AFVs and conventional vehicles-are still the most important reason to switch to green technologies, according to a survey among Norwegian battery electric-vehicle (B-EVs) drivers [34].

\subsection{Relevance of Fiscal Policies on the Competitiveness of AFVs}

Thus, even if there are several psychologic/emotional as well as cultural/sociologic aspects that certainly influence customer decisions, the author concludes that ultimately, customers intend to take rather rational decisions when purchasing a vehicle, mainly based on a "value-for-money calculation". Previous research has already evaluated the impact of fiscal incentives for AFV users as well as of regulations directly affecting manufacturers $[1,5,17,18,25,27,30]$. A vast majority of corresponding studies concluded that financial, technical and public-infrastructure attributes are the key aspects in regard to AFV adoption. Thus, the sales evolution of AFVs must mainly be evaluated from the perspective of customers' financial benefits/disadvantages. Additionally, this is mainly driven by the question of whether AFVs were able to compete with traditional ICE vehicles in regard to their total cost of ownership (TCOs). Apart from official EU fleet emission regulatory targets and member-state funded R\&D projects, the "European Green Vehicle Initiative" was also launched in 2008 in the EU as a public-private partnership, which funded several activities under the EU framework program for research and innovation. In 2017, there were already more than 300 different R\&D programs ongoing in the EU related to technological improvements such as energy storage and control devices, with a total budget of nearly EUR 3 billion, co-founded by the EU and the corresponding member states [56]. Most of the mentioned automotive experts argue that, since the first decade of the 21st century, Europe can be found in the adoption phase of electric vehicles, with initially rather low but constantly growing sales rates. As indicated, this research focused on the four main technologies that have been the most relevant ones: hybrid electric and plug-in hybrid electric vehicles and battery electric vehicles and their "sub-category" of fuel cell electric vehicles. (fuel cell electric vehicles usually use a fuel cell, instead of a battery, to power their on-board electric motor, generally using oxygen from the air and compressed hydrogen. They only emit water and heat and might be seen as the most future-oriented technology if the needed recharging network can be developed.). Special attention needs to be paid to two European markets-Norway and the Netherlands-where significant public incentives were implemented at a very early stage to "' promote' Alternative Fuel Vehicles (AFVs)". Backed by different sorts of public interventions, a notable market change has taken place in these two countries, shifting the market from ICE to AFV engines $[5,6,18,52]$.

In 2014, European Union nations had agreed that carmakers should limit $\mathrm{CO}_{2}$ emissions to 95 grams per kilometer across their entire model range within seven years. Consequently, AFVs were seen as a promising way to help OEMs in cutting $\mathrm{CO}_{2}$ emissions to meet the corresponding EU targets. Based on data from the European Commission Amsterdam Roundtable Foundation, in 2012, the $\mathrm{CO}_{2}$ emissions of all major OEMs clearly had exceeded these initially agreed targets for 2021 [63]. Figure 2 illustrates the significant gap between the actual $\mathrm{CO}_{2}$ emissions of major automotive OEMs in 2012 versus the official emission targets for 2021. 


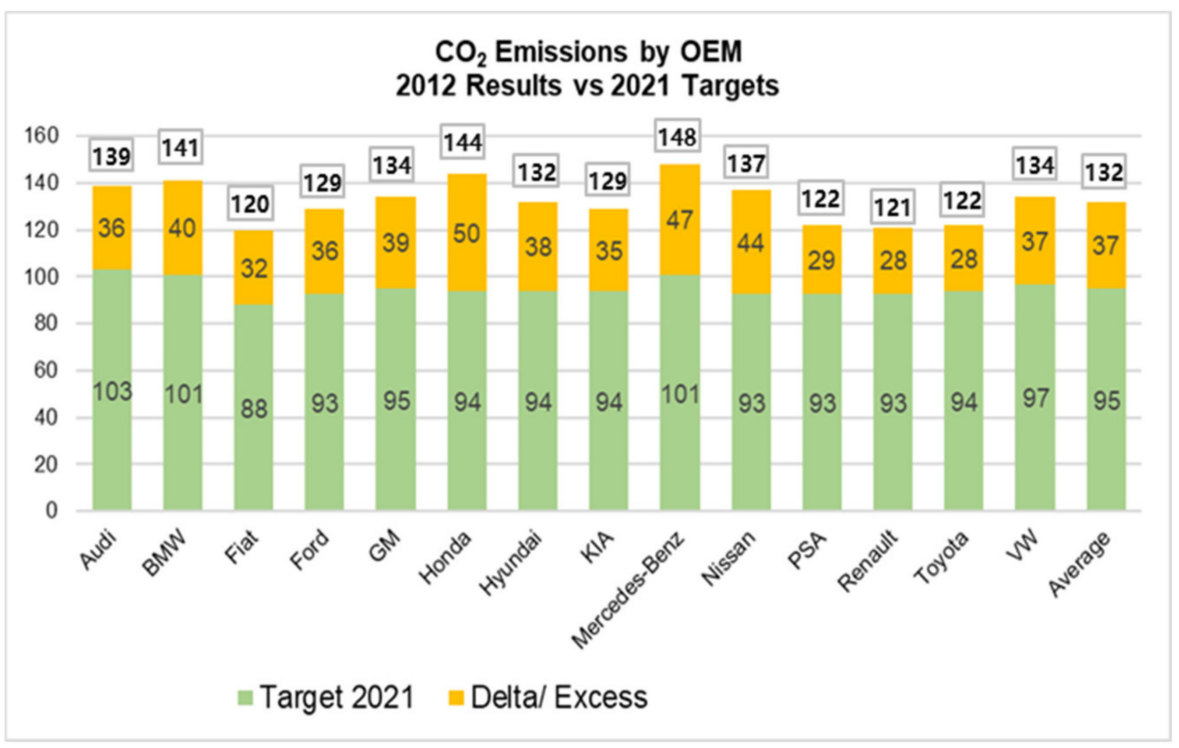

Figure 2. $\mathrm{CO}_{2}$ emissions of selected automotive OEMs in Europe, comparing the status in 2012 with the indicated targets for 2021. Source: author's own elaboration, based on data from the European Commission Amsterdam Roundtable Foundation [63].

\subsection{Net Customer Costs: Comparison of Gasoline vs. Electric Engines by Country}

It is crucial to analyze the corresponding final total cost of ownership (TCO) of AFVs, and of B-EVs in particular, with and without public incentives. By comparing the examples of different European countries, one can evaluate if there was a significant causality between public incentives and the corresponding local AFV sales evolution. In this regard, one must critically evaluate the sustainability and market competitiveness of the AFV technology without public incentives [64].

Figure 3 illustrates the notable difference in public incentives for BEVs across the European markets.

As shown in the chart, only because of heavy incentives could PEVs, such as the Zoe B-EV, compete with their ICE counterparts. In 2013, the B-EV model Renault ZOE had a lower market share in Germany than in France or Norway. A correlation can be found in the ICCT report from 2013, showing us the estimated total cost of ownership for a Renault Clio (with a gasoline engine) versus the mentioned Zoe (battery electric vehicle), including the corresponding local public incentives. Consequently, the higher the public incentives (for example, Norway), the more significant was Zoe B-EV's market share [64].

Hayek had already considered prices and profits to be knowledge-conveying devices. Prices, as well as profits, convey information regarding the supply of and demand for goods and services and the effectiveness of individuals in producing/providing them [22,51]. The development of the price system started to allow us to decide rationally about the allocation of scarce resources [65]. Prices must be seen as signals of the relative scarcity of goods and resources, as prices also help to coordinate human activities [22,65]. As Carl Menger already stated, "value is a judgement which economising men make about the importance of goods at their disposal for the maintenance of their lives and well-being" [66]. In his early works, Hayek constantly emphasized the coordinating role of freely adjusting market prices [22,51]. As one can see in the above chart, a free market is clearly not provided in the European automotive market since the implemented high incentives and taxes have significantly distorted the market. 


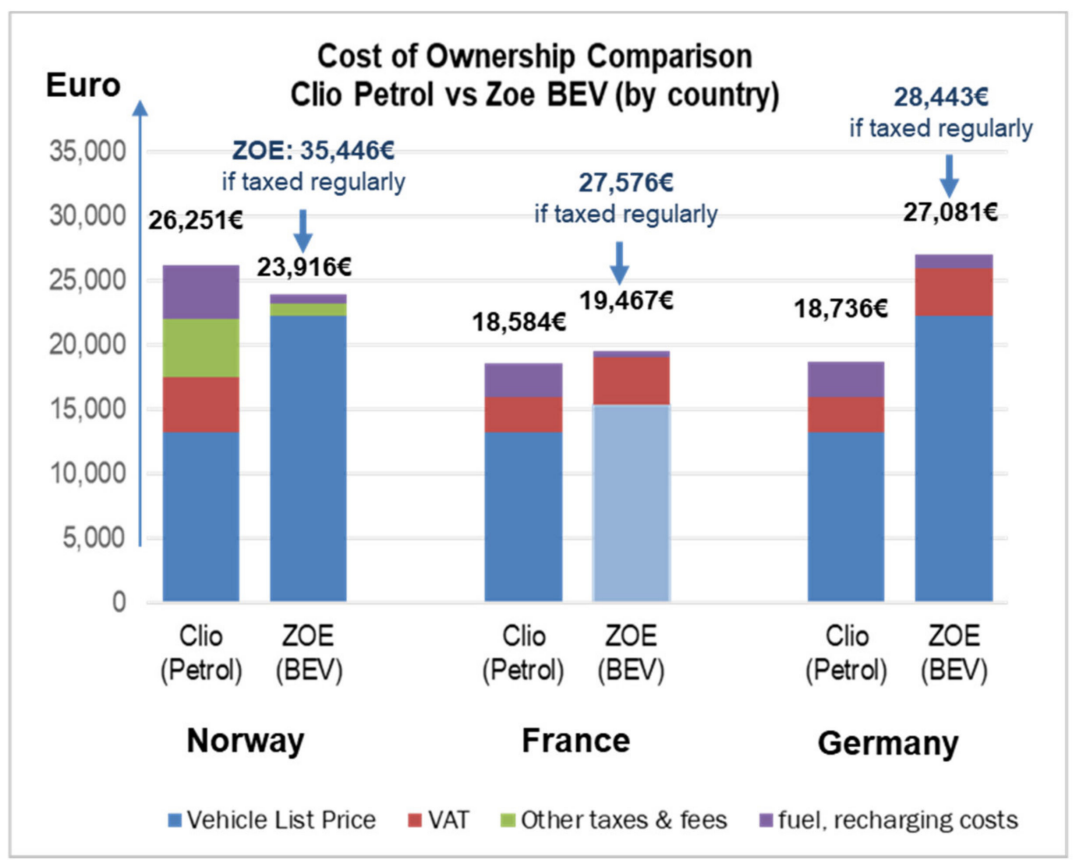

Figure 3. The impact of public incentives on the price competitiveness of BEVs versus ICEs. Source: author's own elaboration, based on data from ICCT, Mock and Yang [18].

As indicated, different public incentive approaches with the aim to increase AFVs registrations were adopted by the individual European countries: before 2015, the use and/or purchase of fossil fuel vehicles causing negative externalities had already been penalized with significant taxes in several European countries, such as Norway, Netherlands and Italy, from which B-EVs and FC-EVs were partially or fully exempt [5]. On the other hand, in the UK and France, direct subsidies had already been given to B-EV owners upon corresponding vehicle purchases. Simultaneously in 2015, in Poland, no public incentives at all were provided for AFVs [34]. The Norwegian vehicle taxation system was heavily taxing fossil fuel vehicles based on curb weight and engine power, as well as on $\mathrm{CO}_{2}$ and $\mathrm{NO}_{\mathrm{x}}$ emissions. In addition, there was generally a high $25 \%$ VAT rate for vehicles, from which B-EVs were exempt [5].

In addition, several other benefits and incentives were implemented, such as the mentioned access to bus lanes, free parking and road toll exemption, and the wide availability of public charging stations providing free electricity for EVs.

In the Dutch taxation system, the vehicle fuel type also played a significant role, as in 2014, a diesel surcharge of EUR 73 per gram of $\mathrm{CO}_{2}$ emitted was imposed on emissions above $70 \mathrm{~g} / \mathrm{km}$. Moreover, the rate of the annual circulation tax has depended on the fuel type (petrol/diesel), while P-HEVs and B-EVs were exempt [67].

It can be concluded that the Norwegian concept of providing tax exemptions, e.g., for the registration and circulation tax, mainly promoted big alternative fuel vehicles, whereas the lump-sum subsidies provided, e.g., France favored the purchase of small AFVs. Moreover, due to a lack of Budget transparency, it cannot be assured that taxes and fines related to "penalizing pollution" have mostly been "ring-fenced", meaning that the corresponding government gains were truly allocated to projects protecting or enhancing the environment.

However, other important non-fiscal/non-purchase price-related factors can influence sales development. B-EV sales significantly increased from 2010 to 2015 in Norway, Netherlands, UK and France, even if simultaneously direct public incentives for B-EVs remained stable [35]. Thus, it is crucial to note that from 2010 to 2014, the number of annual vehicle launches with an alternative fuel technology engine constantly increased. More diversity and more availability of PEV models on the market were considered of major importance to increase the PEV market share. A particular focus was on PH-EV model versions, as the 
PH-EV technology is often considered as the most appropriate transition technology from ICE to B-EV technologies [67]. Consequently, Figenbaum et al. argued that the significant growth was mainly due to four aspects [35]:

(1) A general customer awareness increase for AFVs;

(2) New B-EV model launches leading to a wider product variety;

(3) Optimization and densification of the recharging network;

(4) An optimized driving range due to improved technologies.

\subsection{Fiscal Incentives and Their Impact on Price Competitiveness and Sales Evolution}

In order to define the impact of fiscal incentives on the purchase decision of consumers, one needs to calculate all fiscal incentives and see them in comparison with the net price of the individual PEV. The total amount of all direct monetary incentives is the sum of all direct subsidies (e.g., upfront discounts) as well as the monetary differences in regard to dues and taxes such as the VAT, registration tax or circulation tax for PEVs versus their most similar ICE counterparts. With this relatively basic calculation in which other aspects such as local/municipal taxes or possible free parking spaces for PEVs are not yet included, we still obtain a helpful indication of how significant public interventions were on PEV market competitiveness [64].

Apart from fiscal incentives to promote AFVs, there are also clear signs for European governments to generally ban petrol and diesel vehicles from the market. In 2018, the French government announced that France would end sales of diesel and petrol and vehicles by 2040. Prof David Bailey from Aston University said this French law would provide a clear signal to automotive manufacturers and consumers that the transition towards the increased importance of electric cars is significantly accelerated. The European Environment Agency had confirmed that the French car manufacturers Peugeot, Citroën and Renault ranked first, second and third on a 2016 list of large car manufacturers with the lowest carbon emissions [68]. Consequently, one may speculate that the official aim of "environmental protection" was actually meant to camouflage a new form of national protectionism, as the laws passed by the French government were likely to benefit first and foremost the local French brands.

Even more radical are the targets of Norway, where already by 2025 , only vehicles with a PEV technology should be sold [69]. The Dutch government followed a very similar plan, and other countries have also floated the idea of banning cars powered by an internal combustion engine, but without having passed concrete laws yet. In this scenario, PEVs, which are currently already heavily state-subsidized, would no longer have to compete with petrol and diesel vehicles at all. Public interventionism would completely distort the market, not allowing any form of competition between PEVs and vehicles with an internal combustion engine.

\subsubsection{AFV Sales Evolution}

The following charts demonstrate the annual plug-in car sales' evolution from 2011 to 2019. As indicated, the term plug-in electric vehicles (PEV) hereby refers to both battery electric vehicles (B-EV) and plug-in hybrid vehicles (PH-EV). In 2011, the global PEV sales had only reached a total of approximately 60,000 units, whereas six years later, in 2017, the annual PEV sales already reached 1.2 million units. However, in 2017 the PEV total market share was still relatively low, at approximately $1.3 \%$ of the total market [70]. Thus, even if the uptake of PEVs was notable, most of the official PEV adoption targets set by public institutions at the beginning of the 21st century were not met by 2018. Figure 4 is referring to the discussed increase in PEV sales across the globe in the period from 2011 to 2019. 


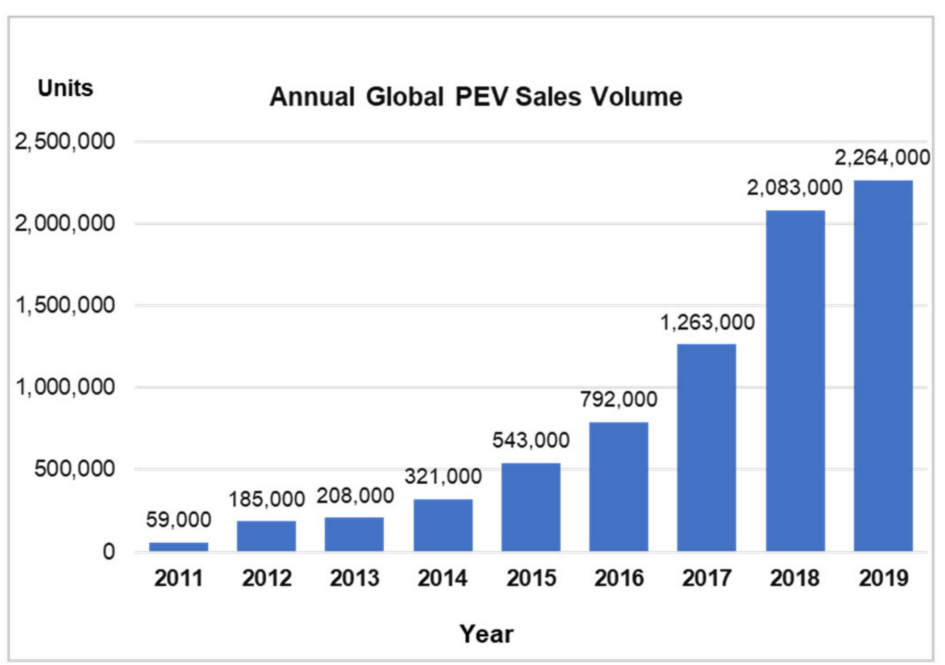

Figure 4. Annual global PEV sales (2011-2019, for passenger cars and light-duty vehicles). Source: author's own elaboration, based on data from JATO, Hertzke et al. [71].

In 2017, global sales of new electric vehicles (combining B-EVs and PH-EVs) passed 1 million units for the first time ever [70]. In 2017, pure electric vehicles (B-EVs) made up $66 \%$ of all global PEV sales, while B-EVs sales grew faster than those of plug-in hybrid vehicles (PH-EVs) [71].

However, this general global picture does not properly reflect that the specific individual markets have shown very different powertrain preferences and are also being influenced by public regulations and other public interventions [43]. Figure 5 illustrates the significant differences between selected markets in regard to the individual local PEV sales share evolution.

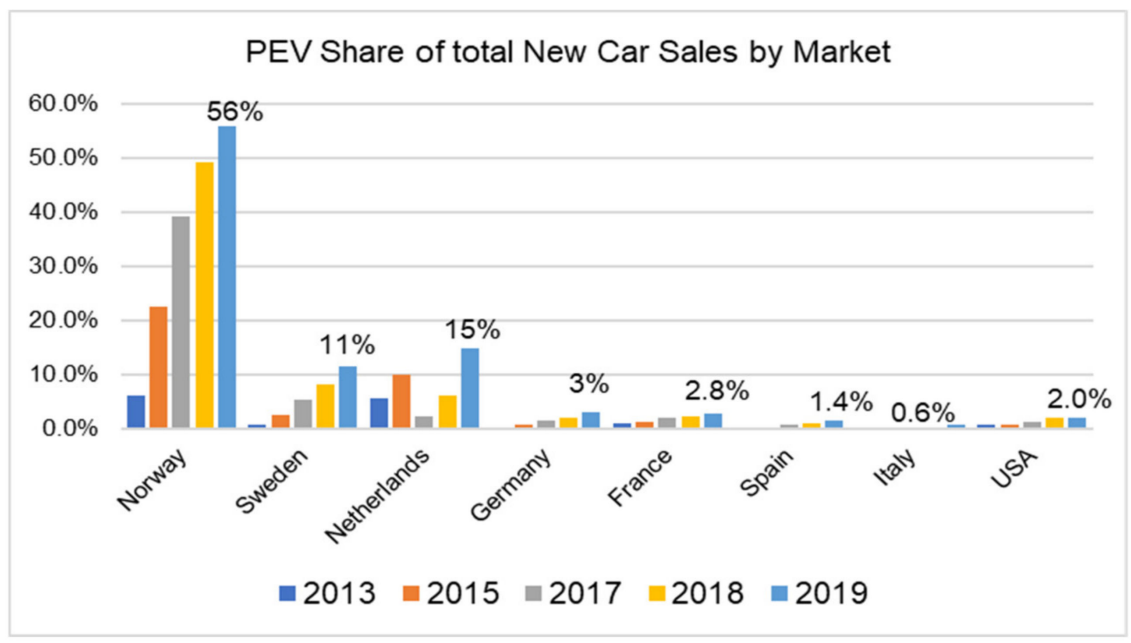

Figure 5. PEV volume share of the total annual new car sales by market. Source: author's own elaboration, based on data from Dataforce [72].

In France, the registration of new B-EVs increased from only 184 units in 2010 to 32,203 units in 2018, which represented a market share of $1.4 \%$ of all new car registrations in 2018. The most sold plug-in electric vehicle from 2013 to 2019 was Renault's Zoe. As previously stated, in 2008, the French government introduced a "bonus-malus system", which was based on a purchase incentive for low emission vehicles and a penalty fee (malus) for the purchase of high-emission vehicles. Moreover, in 2015, the French government introduced an additional bonus for purchases of all-electric vehicles (B-EVs) connected 
to the simultaneous scrappage of diesel-powered cars if they were in circulation before 1 January 2001 [52].

In Germany, cumulative registrations of all PEVs totaled 305,787 units between January 2010 and December 2019, consisting of 168,396 all-electric cars (B-EVs) as well as 137,391 PH-EVs. Although a constant volume growth could not be denied, the evolution was significantly less impressive than what had been foreseen by several politicians, journalists and consultancies [52]. In 2010, and under its "National Platform for Electric Mobility", German Chancellor Angela Merkel had set the target of putting one million electric vehicles on German roads by 2020. This far too optimistic target was not only a "German phenomenon", but also most other European governments had defined similar, overly ambitious goals. Figure 6 illustrates the corresponding gap between the indicated target and the actual sales evolution of PEVs in Germany.

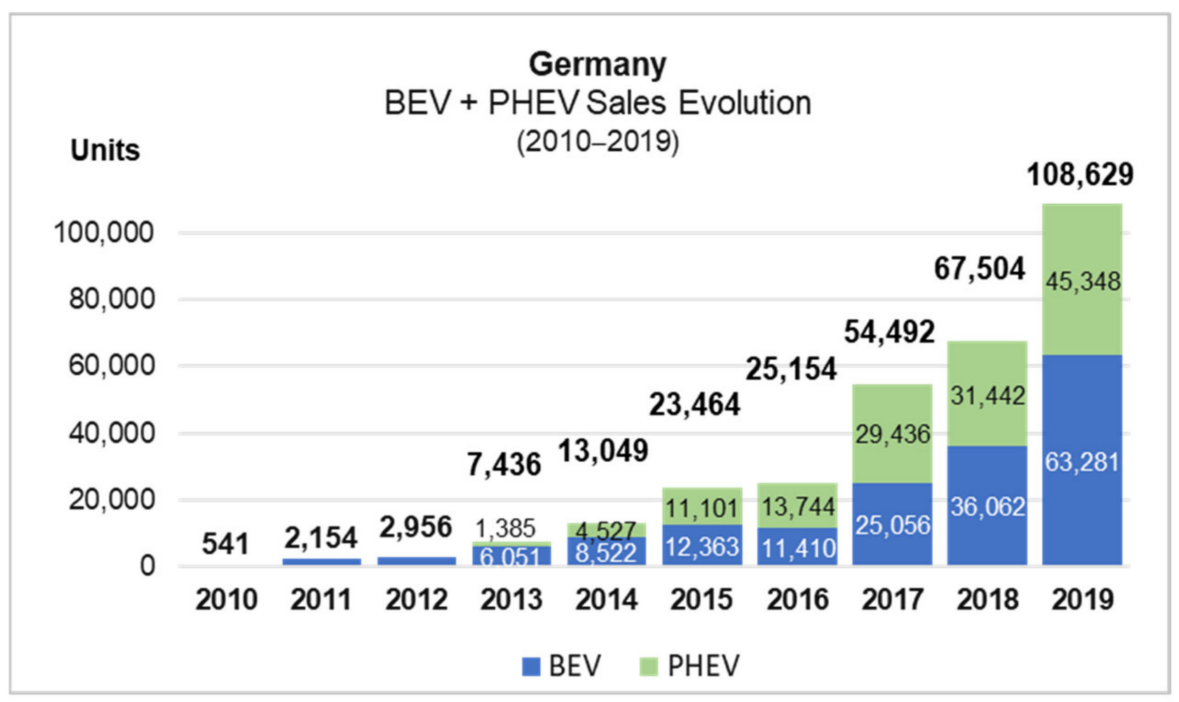

Figure 6. Annual sales of new PEVs in Germany (passenger cars only). Source: author's own elaboration, based on data from IEA [52].

In 2016, a national incentive scheme was approved for Germany, including purchase subsidies and public support for the expansion of the charging station network. Although Merkel's mentioned PEV volume target was missed, corresponding vehicle sales significantly increased throughout the past years, thanks to optimized vehicle technologies with increased driving ranges, a (subsidized) growing recharging infrastructure as well as other public incentives and tax benefits. In particular, $\mathrm{PH}-\mathrm{EV}$ sales had only seen a rather disappointing sales evolution up until the year 2019 [4], but experienced a significant boost in 2020, mainly due to further optimized public incentives (including a new car purchase bonus as well as tax benefits, particularly for company car users) [52].

In the Netherlands, new car sales of B-EVs significantly increased throughout the past years, whereas registrations of PH-EVs meanwhile even slightly decreased. Until 2016, the Dutch PEV market was dominated by plug-in hybrid electric vehicles (PH-EVs), when the Dutch government decided to reduce the relative tax advantages of PH-EVs. In 2016, as of January 1st, the registration fee for PH-EVs increased from $7 \%$ to $15 \%$ of its list price, whereas for all-electric vehicles (B-EVs) and vehicles with conventional internal combustion engines, the fees remained stable at $4 \%$ and $25 \%$, respectively. Moreover, B-EVs have special access to parking spaces in Dutch cities such as Amsterdam, and free charging is provided in public parking spaces. The Netherlands can be seen as a good example of how public interventions helped to significantly boost PEVs, while then also moving customer demand from PH-EV models towards B-EVs [52]. Figure 7 is illustrating the shift from PH-EVs to B-EVs in the Netherlands in the period from 2011 to 2019. Accordingly, Table 1 shows the corresponding concrete figures, showing a clear tendency towards BEVs since 2016. 


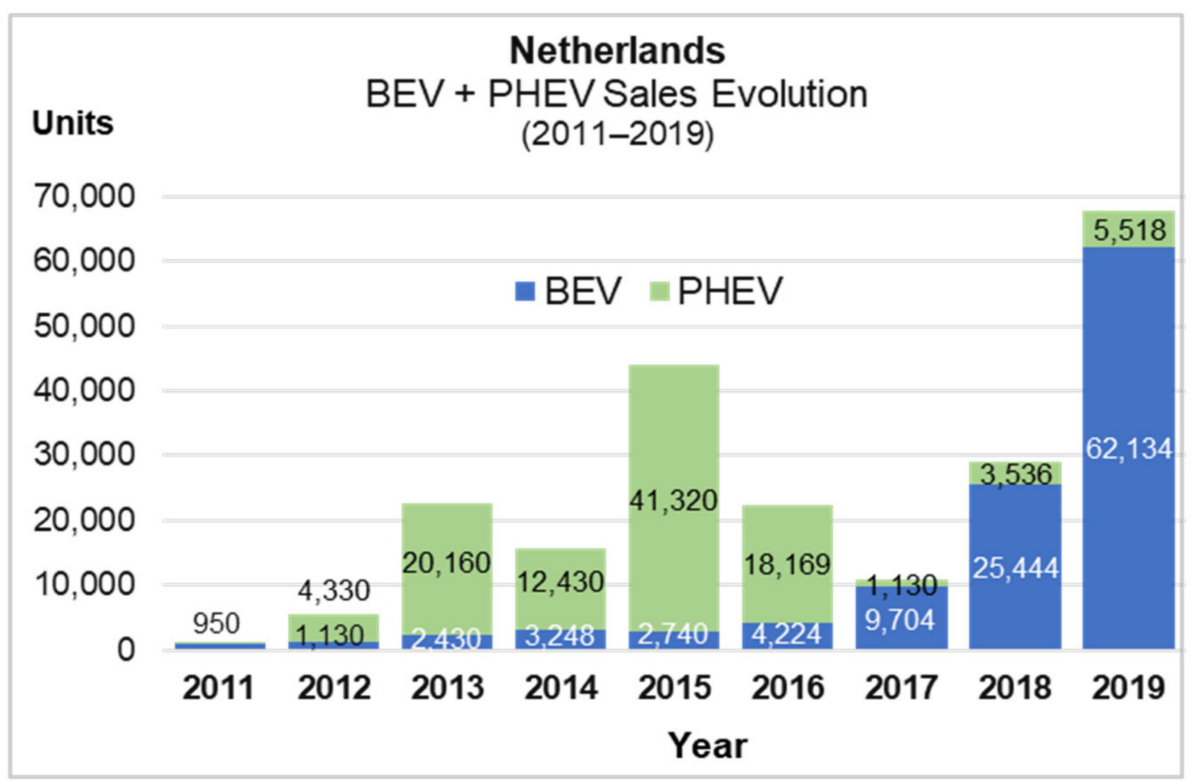

Figure 7. PEV sales evolution in the Netherlands. Source: Author's own elaboration, based on data from IEA [52].

Table 1. PEV sales evolution in the Netherlands. Source: Author's own elaboration, based on data from IEA [52].

\begin{tabular}{ccccccc}
\hline Netherlands (Year) & $\mathbf{2 0 1 3}$ & $\mathbf{2 0 1 4}$ & $\mathbf{2 0 1 5}$ & $\mathbf{2 0 1 6}$ & $\mathbf{2 0 1 7}$ & $\mathbf{2 0 1 8}$ \\
\hline $\begin{array}{c}\text { Total new B-EV registrations } \\
\text { (units) }\end{array}$ & 2430 & 3248 & 2740 & 4224 & 9704 & 25,444 \\
$\begin{array}{c}\text { Total new PH-EV registrations } \\
\text { (units) }\end{array}$ & 20,160 & 12,430 & 41,320 & 18,169 & 1130 & 3536 \\
\hline
\end{tabular}

Meanwhile, in Norway, the market growth of PEV sales was even more stable and impressive than in the Netherlands. Norway has the world's largest PEV ownership per capita. The Norwegian government implemented several incentives to promote the adoption of PEVs, such as an exemption of B-EVs from the annual road tax, public parking fees and toll payments. As of January 2018, at least 24 out of 58 major municipalities kept free parking for B-EVs. By 2016, PEVs had already captured a market share of $29.1 \%$ of the total Norwegian new car registrations, which rose to $39.2 \%$ in 2017 and then to $49.1 \%$ in 2018. In 2019, the PEV market share of new car registrations even rose to $55.9 \%$, which meant that in 2019, more than every second new passenger car sold in Norway was a B-EV or PH-EV. In October 2018, Norway became the first country globally in which 1 in every 10 registered passenger cars was a PEV [52,71]. Table 2 illustrates the significant PEV sales increase (individually shown for PH-EVs and B-EVs) in Norway in the period from 2013 to 2018.

Table 2. PEV sales evolution in Norway. Source: Author's own elaboration, based on data from IEA [52].

\begin{tabular}{ccccccc}
\hline Norway (Year) & $\mathbf{2 0 1 3}$ & $\mathbf{2 0 1 4}$ & $\mathbf{2 0 1 5}$ & $\mathbf{2 0 1 6}$ & $\mathbf{2 0 1 7}$ & $\mathbf{2 0 1 8}$ \\
\hline $\begin{array}{c}\text { Total new B-EV } \\
\text { registrations (units) } \\
\begin{array}{c}\text { Total new PH-EV } \\
\text { registrations (units) }\end{array}\end{array}$ & 10,078 & 21,686 & 25,788 & 24,245 & 33,080 & 46,132 \\
\hline
\end{tabular}


In Poland, public incentives were significantly lower than in the previously mentioned markets, such as Norway, Netherlands and Germany. In 2009, the Polish charging station infrastructure was developed in cities such as Gdańsk, Katowice, Kraków and Warsaw with EU funds, but public support by local governments was rather limited. Consequently, due to the lack of market-distorting public incentives and only relying on the actual customer demand, sales figures for PEVs were extremely low in Poland. Sales of new B-EVs rose from 70 units in 2015 to only 620 units in 2018, representing an insignificant $0.12 \%$ of the Polish automotive market in 2018 [52,71].

Moreover, in Italy, sales growth of PEVs was slower than in other European markets. By December 2015, the cumulative registrations of all PEVs only reached approximately 6100 units, consisting of $4580 \mathrm{~B}-\mathrm{EV}$ units and $1550 \mathrm{PH}-\mathrm{EV}$ s. Even in 2018, the annual volume of PEV sales was relatively low, at approximately 10,000 units [52,71].

Overall, one can say that while manufacturers have shown progress in developing more competitive PEVs with a wider driving range, well-performing engines and superior styling, there are still several significant challenges to accelerate PEV sales in a sustainable way. Simultaneously, several new automotive brands and mobility providers were founded or restructured with a strong focus on PEVs. These interesting new start-ups include the Chinese companies NIO Inc. and Aiways Ltd., as well as the Chinese-US-American corporate Lucid Motors and Fisker Automotive Inc. While the Chinese brands NIO and Aiways focus on electric SUVs, such as NIO's coupe SUV "EC6" and Aiways "U5", Lucid Motors plans to initially target luxury customers with its sporty model "Air". Other Asian OEMs entering the European market with PEV technologies are the Vietnamese Vingroup with its brand VinFast, as well as the Chinese OEMs Xiaopeng Motors (Xpeng), BYD Company Limited, Great Wall Motors (with its brands WEY and ORA) and "SAIC Motor Corporation Limited" (with the formerly British automotive brand MG), as well as the brands Polestar and Lynk and Co by Geely Auto Group [46]. Whether these new brands, particularly the recently-founded start-ups, will succeed in Western markets cannot be defined at this stage. The author of this paper assumes that ultimately not more than two or three of the mentioned new players will be able to successfully establish themselves in the European market. For them, it will be crucial to establish an efficient supply chain and a manufacturing structure that successfully combines fast production processes and highquality products with a reliable after-sales and service network. Even more so, a customerfriendly network of service points and a fast supply of spare parts must be assured.

Figure 8 illustrates the market share of PEVs among the annual new passenger car registrations in the period from 2013 to 2019. The analysis shows that PEV increase was particularly significant in countries located in the northwest of Europe. In smaller Nordic countries, such as Norway, the Netherlands, Iceland and Sweden, an impressive sales growth of PEVs occurred [71,72].

However, by 2019, in the larger European markets such as France, Germany and the United Kingdom, PEVs were still a niche product. Due to the increasingly strict $\mathrm{CO}_{2}$ emission regulations, a growing range of PEV models and the mentioned economies of scale, the market share of PEVs is expected to notably increase across Europe [52,72]. 


\begin{tabular}{|c|c|c|c|c|c|c|c|}
\hline Country & $\mathbf{2 0 1 9}$ & $\mathbf{2 0 1 8}$ & $\mathbf{2 0 1 7}$ & $\mathbf{2 0 1 6}$ & $\mathbf{2 0 1 5}$ & $\mathbf{2 0 1 4}$ & $\mathbf{2 0 1 3}$ \\
\hline Norway & $55.9 \%$ & $49.1 \%$ & $39.2 \%$ & $29.1 \%$ & $22.4 \%$ & $13.8 \%$ & $6.1 \%$ \\
\hline Iceland & $22.6 \%$ & $19 \%$ & $14.05 \%$ & $4.6 \%$ & $2.93 \%$ & $2.71 \%$ & $0.94 \%$ \\
\hline Netherlands & $15.1 \%$ & $6.5 \%$ & $2.6 \%$ & $6.7 \%$ & $9.9 \%$ & $3.87 \%$ & $5.55 \%$ \\
\hline Sweden & $11.4 \%$ & $8.2 \%$ & $5.2 \%$ & $3.5 \%$ & $2.62 \%$ & $1.53 \%$ & $0.71 \%$ \\
\hline Finland & $6.9 \%$ & $4.7 \%$ & $2.57 \%$ & $1.2 \%$ & $\mathrm{n} / \mathrm{a}$ & $\mathrm{n} / \mathrm{a}$ & $\mathrm{n} / \mathrm{a}$ \\
\hline Portugal & $5.7 \%$ & $3.6 \%$ & $1.9 \%$ & $\mathrm{n} / \mathrm{a}$ & $\mathrm{n} / \mathrm{a}$ & $\mathrm{n} / \mathrm{a}$ & $\mathrm{n} / \mathrm{a}$ \\
\hline Switzerland & $5.5 \%$ & $3.2 \%$ & $2.55 \%$ & $1.8 \%$ & $1.98 \%$ & $0.75 \%$ & $0.44 \%$ \\
\hline China & $4.9 \%$ & $4.2 \%$ & $2.1 \%$ & $1.31 \%$ & $0.84 \%$ & $0.23 \%$ & $0.08 \%$ \\
\hline Andorra & & & $5.6 \%$ & $0.81 \%$ & $\mathrm{n} / \mathrm{a}$ & $\mathrm{n} / \mathrm{a}$ & $\mathrm{n} / \mathrm{a}$ \\
\hline Denmark & $4.2 \%$ & $2 \%$ & $0.4 \%$ & $0.6 \%$ & $2.29 \%$ & $0.88 \%$ & $0.29 \%$ \\
\hline Austria & $3.5 \%$ & $2.6 \%$ & $2.06 \%$ & $1.6 \%$ & $0.90 \%$ & $\mathrm{n} / \mathrm{a}$ & $\mathrm{n} / \mathrm{a}$ \\
\hline Belgium & $3.2 \%$ & $2.5 \%$ & $2.7 \%$ & $1.8 \%$ & $\mathrm{n} / \mathrm{a}$ & $\mathrm{n} / \mathrm{a}$ & $\mathrm{n} / \mathrm{a}$ \\
\hline Ireland & $3.1 \%$ & $1.57 \%$ & $0.72 \%$ & $0.48 \%$ & $0.46 \%$ & $0.27 \%$ & $\mathrm{n} / \mathrm{a}$ \\
\hline Germany & $3.0 \%$ & $1.9 \%$ & $1.58 \%$ & $1.1 \%$ & $0.73 \%$ & $0.43 \%$ & $0.25 \%$ \\
\hline Canada & $3.0 \%$ & $2.2 \%$ & $0.92 \%$ & $0.58 \%$ & $0.35 \%$ & $0.28 \%$ & $0.18 \%$ \\
\hline UK & $2.9 \%$ & $2.53 \%$ & $1.86 \%$ & $1.37 \%$ & $1.07 \%$ & $0.59 \%$ & $0.16 \%$ \\
\hline \hline
\end{tabular}

Figure 8. Market share of PEVs (B-EV + PH-EV) among annual new car registrations. Source: author's own elaboration, based on EAFO and data from Dataforce [52,72].

\subsubsection{Quantitative and Qualitative Status of the AFV Implementation}

In the following section, the author intends to illustrate the evolution of PEV adaptation within the different markets throughout recent years. The author does not only refer to the pure quantitative evolution of PEV sales but also to how automotive experts at companies such as McKinsey and Bloomberg consider the individual competitiveness of automotive OEMs.

The following chart, based on an analysis by McKinsey in 2018, shows the four stages of a disruptive trend. It indicates that the so-called "electric vehicle disruption" is already inevitable in Norway, which has seen significant growth in PEV-sales. Apart from significant public incentives for PEVs, the rollout of more attractive, better-performing PEV models in key high-demand segments was also a major driver for a relevant sales uptake in several markets [33,70]. As noted, the increased investments by automotive OEMs into alternative fuel technologies are also driven by ambitious emissions targets (especially in China and Europe) and announcements by several national governments (or individual states and cities) around the world to set end-dates for the registration of dieseland gasoline-powered vehicles [68,69]. Accordingly, the US-American State of California, as well as France and the United Kingdom, had announced that local sales of ICE vehicles should be terminated by the year 2040 [71].

Figure 9 illustrates the status of selected markets regarding their maturity as a BEV market. It is based on mentioned McKinsey's (2018) research, indicating that by 2018, markets such as India, the USA and Germany were still in the first phase of the PEV market adoption. Markets such as China and Sweden were already considered to be more "advanced", being in the second phase, although a truly critical mass of market adoption was not achieved [52,71].

By 2018, only Norway achieved a PEV market adoption by a considerable critical mass [71]. Thus, the mentioned considerable public supports to increase the competitiveness, and general customer acceptance of PEVs in Norway have apparently been effective.

However, the author of this paper argues that due to its tremendous size, the evolution of the impressive Chinese automotive market is likely to have a significantly higher global impact than that of Norway. Correspondingly, the sales evolution of PEVs in China should herein be illustrated in more detail. Figure 10 illustrates the annual sales volume evolution of B-EVs and PH-EVs in China within the period from 2011 to 2019. The stated numbers indicate the significant volume increase which had occurred, particularly from 2014 to 2018. 


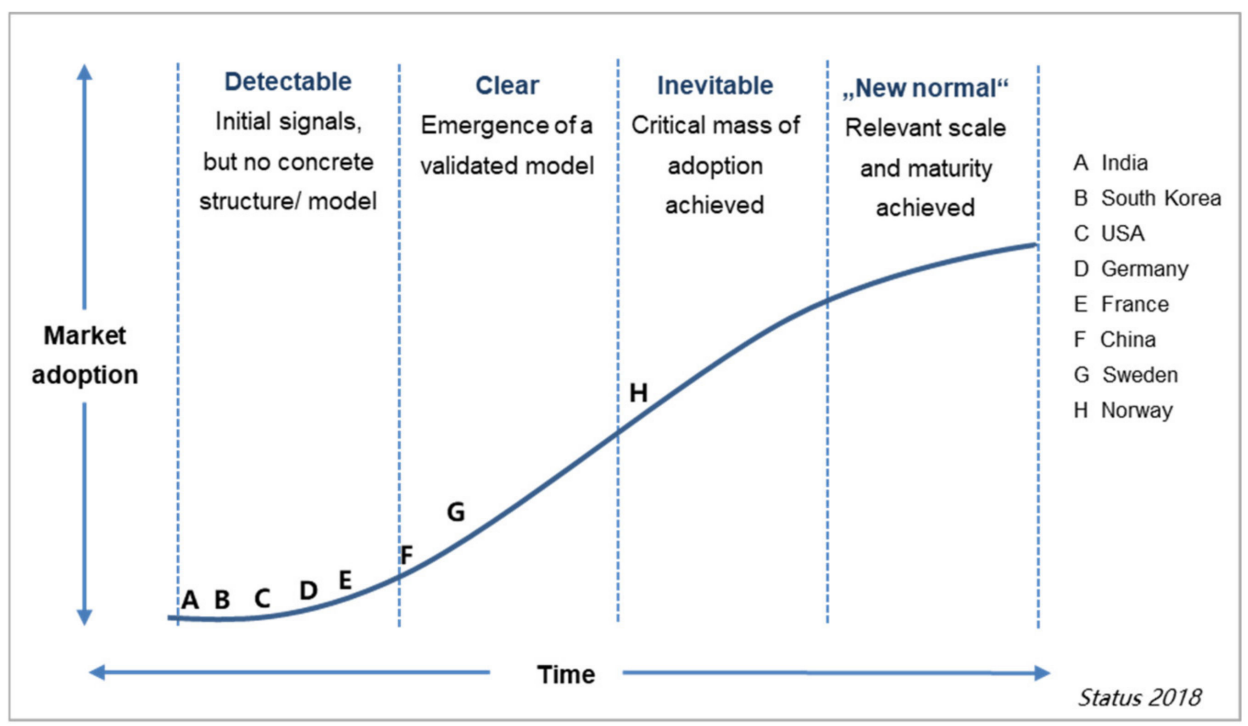

Figure 9. The 4 stages of disruptive trends: stages of BEV market adaption by country. Source: author's own elaboration, based on IEA market data and Hertzke et al. [52,71].

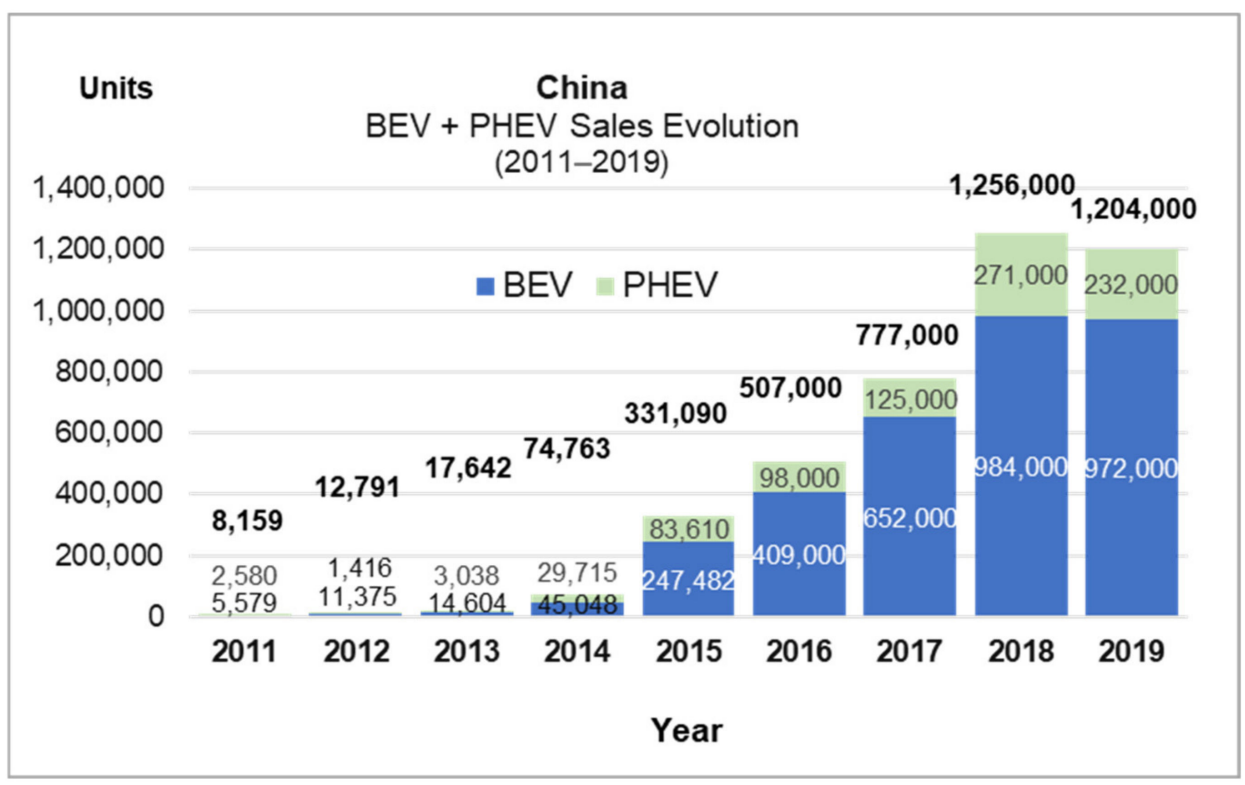

Figure 10. Annual PEV sales evolution in China. Source: author's own elaboration, based on data from IEA [52].

In 2019, China was by far the largest PEV (B-EV + PH-EV) market in the world, with a total of 3.4 million highway-legal PEV passenger cars in use, representing $47 \%$ of the global PEV fleet at that point in time. Since 2011, the combined sales of all classes of PEVs (passenger cars and commercial vehicles) totaled almost 4.2 million by the end of $2019[52,71]$. In the following chart, the author intends to analyze how well individual economies are prepared for the transition towards an automotive market that is likely to be shaped by PEVs. This analysis shows the countries' individuals from 2014 to 2018 and is conducted from two perspectives: from a consumer's perspective as well as from an automotive producer's point of view. A comparison of EVI performance over time indicates that China has already overtaken the United States and Germany when combining these two "EVI scores". In McKinsey's 2018 overall EVI rankings, China was only outperformed by Norway in the "EVI market score" (representing the consumer demand side) while reinforcing its leading position in the "industry EVI analysis" (which represents 
the "supply" side of the equation) [71]. In other words, while Norway is considered the most advanced market (consumer-wise) in regard to the expected shift towards plug-in vehicles, China is seen as the economy in which local automotive producers are most prepared for this structural shift.

Figure 11 indicates that the index of several markets changed quite significantly from 2014 to 2018. China outperformed other countries in regard to the evolution of its market index as well as regarding its industry index. In regard to the "market EVI scoring", China improved its position by providing significant monetary and non-monetary incentives, offering its consumers a wider range of models, as well as by increasing investments into the charging infrastructure. Moreover, China clearly optimized its "industry EVI scoring", significantly increasing its EV production and component shares. Whereas France and Germany only slowly advanced in regard to increasing the local EV market share and the domestic production of EVs, Italy's corresponding market-side performance had even decreased by 2018 [71].

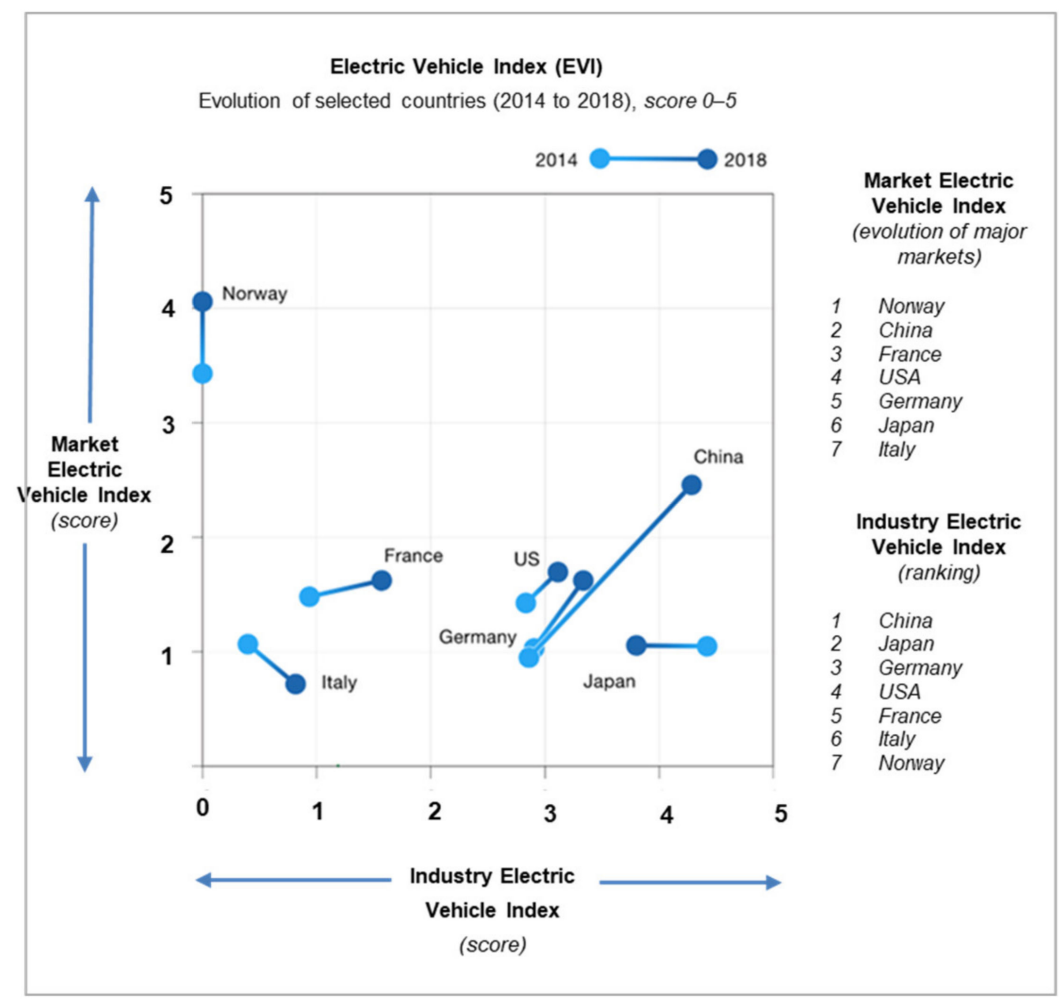

Figure 11. Electric Vehicle Index development in selected markets (2014-2018). Source: author's own elaboration, based on IEA market data and Hertzke et al. [52,71].

Thus, within the period from 2014 to 2018, some markets such as Italy did not show relevant progress in regard to a PEV adaptation. In the same period, the USA showed a slow adaptation, while the development in France and Germany was already slightly larger, but still at a relatively low level. The only market which significantly increased its EV development index, in regard to its market index as well as regarding its industry index, was China [71].

However, one must consider that due to the limited price competitiveness of current EV batteries, China's and Norway's leadership in EVI scores has only been possible due to significant public interventionism $[1,4,43]$. China and Norway have some of the world's highest levels of spending on consumer and supply-side subsidies, which can only be financed at the citizen's/taxpayers' expense [1,43]. In 2009, the Chinese government adopted a thorough plan to turn China into the world leader in EV production, focusing on four main goals: creating a world-leading PEV industry, assuring energy security while 
also reducing urban air pollution, as well as to reduce local carbon emissions. In June 2012, the Chinese State Council published a plan to develop the domestic car industry, providing public incentives with the aim to achieve an annual target of 5 million new PEV sales by 2020 [52].

Correspondingly, in a truly free market economy, it is highly unlikely that alternative fuel vehicles could have already gained a significant market share before the establishment of true price competitiveness versus ICE vehicles. Thus, the self-critical question all laissezfaire economists must ask themselves is: "Do the ends justify the means?" In other words, has public interventionism been necessary to create a world with less pollution, less global warming and less negative externalities? More importantly, can the seen public incentives and other forms of public interventionism be justified if ultimately automotive OEMs (due to their significant R\&D investments and the expected economies of scale) are able to produce and sell PEVs at competitive prices without any public incentives? To go a step further, will those automotive OEMs, which are directly influenced (and protected) by their national government, be more competitive than traditional western OEMs that have been less controlled by public structures, such as BMW? Dudenhöffer agrees that it is very unlikely that Chinese automotive OEMs could have become so advanced in the development of plug-in electric vehicles without the significant interventionism and financial support by the Chinese state [43,44]. In other words, can China serve as an example that demonstrates that public interventionism is successful in preparing local OEMs to be more competitive in the future global automotive market? The author of this paper opposes this position, as in a truly free market, potentially other alternative fuel concepts could have been preferred by the market players for being economically more efficient and ecologically more sustainable than PH-EV and B-EV engines.

As initially stated, the implemented public incentives to increase the attractiveness of AFVs for consumers are often justified by the aim to protect the environment and to reduce negative externalities, such as air pollution and $\mathrm{CO}_{2}$ emissions [1]. It is not denied that battery electric vehicles (B-EV) can reduce greenhouse gas (GHG) emissions if powered with truly "clean" renewable energy. Accordingly, many consumers consider full electric vehicles to be more sustainable than hybrid vehicles, given that as of today, the latter still create some air-polluting emissions while driving. However, when referring to environmental protection and negative externalities, one must also consider that electric vehicles create a demand for additional electric power generation and, more importantly, that the current electric power generating industry has failed to properly switch to more sustainable energy sources [1,4]. Thus, in most countries, the power generation which is necessary to fuel "green" B-EVs ultimately also depends on the use of fossil fuels. Thus, current B-EVs still cause significant pollution for being are run on electricity that, in most European countries and the United States, is still mostly generated from the combustion of fossil fuels. Moreover, current PEVs are run by intricate lithium-based batteries, which are difficult to dispose of and which are harmful to the environment, containing toxic metals such as nickel, lead and copper, as well as toxic and flammable electrolytes $[1,4,17]$.

\subsubsection{New Car Sales Evolution: Annual Global Light-Duty Vehicles-ICEs vs. EVs}

Bloomberg New Energy Finance (2020) forecasts that by the year 2040, electric cars will dominate the global automotive market, stating that PEVs (with all its variances) will make up $28 \%$ of all passenger vehicle sales by 2030 and $58 \%$ by 2040 . This significant increase is expected to be driven by a strongly increasing variety of PEV models, falling lithium-ion battery prices, reduced per-unit production costs, further public regulations and fiscal policies, as well as an increasing acceptance by consumers. Based on the same study, Bloomberg New Energy Finance considers production cost for certain PEVs to achieve price parity versus internal combustion engines (ICEs) by approximately 2025 . This calculation is assuming that production costs can mainly be decreased due to economies of scale as well as due to possibly reduced per-unit research and development costs [73,74]. 
Concrete indications for increasing PEV sales volumes will reassure car manufacturers to invest in larger production facilities for PEVs, leading to reduced per-unit costs. Correspondingly, in particular, regarding B-EVs, economies of scale will drive down battery costs, reducing total production costs of electric vehicles, enabling them to achieve much wider-scale adoption [74]. The author agrees with Dudenhöffer that mentioned economies of scale could then occur, leading to cost advantages obtained by their scale of operation (typically measured by the amount of output produced) [44,75]. This scenario is illustrated in Figure 12.

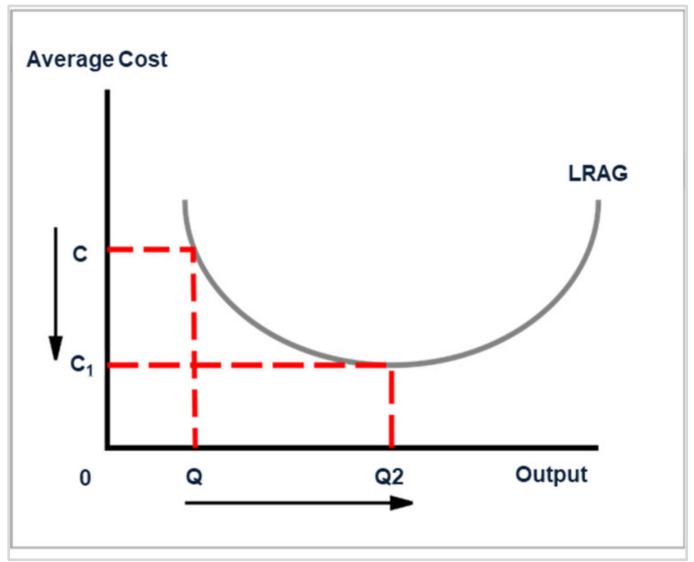

Figure 12. Economies of scale. Sources: author's own elaborations, based on Smith and Mill, as explained by Story [75].

One must also consider what is called "the experience curve" which refers to the effect that the higher the cumulative volume of production $(X)$, the lower the direct cost per new unit produced (C). As shown in Figure 13, there shall generally be a reduction in the average cost of production of a particular product as a consequence of an increase in the company's experience. As a consequence, the time and cost of producing a unit of output will then be reduced. Thus, an experience curve is convex and has a downward slope, as shown in the following diagram $[74,75]$.

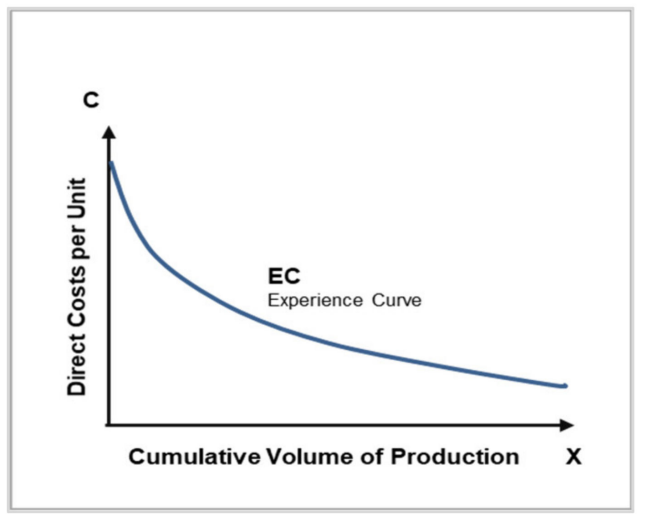

Figure 13. Experience curve. Sources: Author's own elaborations, based on Wright and Henderson, as explained by Story [75].

Additional crucial aspects are the constantly increasing mileage/driving range of new, optimized PEV concepts, as well as the growing network of recharging stations [37].

Moreover, it can be expected that plug-in hybrids (PH-EVs) will lose relevance within this period, being replaced by battery-only vehicles (B-EVs), for which competitiveness is constantly being increased due to optimized engines with longer driving ranges. Moreover, Bloomberg declared that while plug-in hybrid electric vehicle (PH-EV) sales would 
play a significant mid-term role in PEV adoption until the year 2025, pure battery-electric vehicles (B-EVs) would subsequently account for the vast majority of all PEV sales for the following years [73]. The share of B-EVs is expected to grow particularly in the passenger car segments, whereas FC-EVs are rather expected to have an opportunity with commercial vehicles/medium and heavy-duty vehicles. Despite the growing general interest in hydrogen technologies in regard to energy production, sales results of FC-EVs in the European automotive market were rather disappointing, particularly for passenger cars. Moreover, the author argues that the narrowed focus of most European governments on promoting PH-EV and, even more so, B-EV technologies must be seen critically. However, throughout the second decade of the 21st century, FC-EVs are forecasted to become significantly cheaper from a TCO perspective, as vehicle development and production costs are expected to decline due to technological advancements and economies of scale $[73,76]$. Thus, apart from the "positive discrimination" (public incentives, free parking spaces, tax reductions, etc.) for PEVs by local governments and public institutions, it is expected that the "negative discrimination" of ICE vehicles (such as the introduction of additional fees and taxes, driving constraints in urban areas, etc.) will further intensify. Therefore, as indicated, ambassadors of the "electric revolution" argue that temporary public incentives were only needed for a limited period of time to "steer" the automotive industry into a more sustainable future. This perspective could present the latest developments on the automotive market as a success story, justifying public interventionism by arguing that in this case, "the result seems to justify the deeds".

\subsection{Summary on Fiscal Policies in the Automotive Industry}

With the recent fiscal policies and legal settings, a proper definition of free-market prices is impossible due to massive public interventionism such as taxes, fees and other regulations [1,4]. It can be argued that the economic boom and real estate bubble seen in the early years of the 21st century showed similarities to the current "boom in eco-friendly car sales". The ultra-lose monetary policies combined with artificial credit expansions that led to the financial crisis of 2007-2009, was caused by monetary policies which distorted the market, creating an artificial demand for credits, increasing unproductive investments into the early stages of production [11,77]. The author concludes that similarly, the recent growth of AFV sales would not have been possible without public interventionism and market-distorting fiscal policies. One may certainly argue that the development of the recharging infrastructure for PH-EVs and B-EVs would have been a challenge without any public support, as these engine technologies rely heavily on proper fuelling infrastructure. This interdependence between necessary, costly fuelling station investments and the competitiveness of AFVs in the market had caused a certain "chicken and egg" problem for which governments, automotive OEMs and gas station providers had blamed each other. Nevertheless, it is argued that if automotive OEMs (or gas station owners) had really seen a significant market demand, proper solutions certainly would have been found by the free markets, as truly free markets have always been able to adapt to changes $[78,79]$. Mises once stated that "it is the speculative capitalists who create the data to which he has to adjust his business and which therefore gives direction to his trading operations." [78].

The recent increase in AFVs cannot be seen as sustainable development, as it is not occurring in a free market, not being based on actual customer demand [80]. Friedman was right in saying that "one of the great mistakes is to judge policies and programs by their intentions rather than their results." [81]. Consequently, the author of this paper argues that, as in the case of monetary policies by central banks, fiscal policies implemented by governments also directly lead to market distortions and malinvestments, which have often led to negative long-term results, ending up in economic crisis [82].

However, when looking at the reality in several corporations, it must also be remembered that in particular within the automotive industry, most OEMs are no more steered by "entrepreneurs", but rather by "managers". Consequently, whereas only a very few brands are still family-owned enterprises, the majority have become global corporations, often 
driven by short-term results necessary to optimize the company performance at the stock markets. Consequently, the traditional concept of entrepreneurs being alert and creative to discover new business opportunities $[23,83]$ while personally investing time and money into their company's long-term success does not fully match with several large corporations. The so-called "principal-agent problem" is an example of moral hazard, in which economic agents (such as managers/employees as well as stockholders of a company) are motivated to act in their own best interests, which are contrary to the long-term interests of the corresponding company.

Thus, from the author's perspective, to fully appreciate the relevance of long-term entrepreneurial success and long-term competitiveness, an understanding of the concepts of "entrepreneurship and competition" developed by F.A. Hayek, Israel Kirzner and Huerta de Soto is seen as crucial $[22,23,65,79]$. Kirzner criticized the approach of many neoclassical economists who mainly concentrated on the concept of "economizing", referring to their focus on the allocation of given means to achieve as fast as possible a set of given (competing) ends. He argued that this was not sufficient to guarantee entrepreneurial success in a dynamic market [23].

From a dynamic perspective, it is much more relevant to be alert, discovering new opportunities than to purely focus on "preventing waste". Thus, within the automotive industry, major decision-makers should also consider truly acting like creative, alert entrepreneurs, focusing on the long-term success of the company and maximizing its competitiveness.

Consequently, the author argues that the public incentives, which were provided to "promote" AFVs, were not only often exaggerated but actually harmful and inefficient from a long-term perspective. It is claimed that in a free market, once customer demand for AFVs had naturally increased, providers and consumers would have found truly adequate solutions by themselves, without public interventions [80]. However, the automotive manufacturers have used these recent years of strong fiscal interventionism to optimize their AFV models in regard to crucial aspects such as product quality, reliability, driving range and needed recharging times. Consequently, due to the seen public subsidies and other public interventions as well as to the corresponding expected economies of scale, by the early 2030 's, several PEVs could likely be price competitive without any further governmental support.

\section{Key Findings and Conclusions on Public Incentives for AFVs}

Conflicts related to energy supply have often been the cause for political tensions between different states and confederations of states [2,29]. Accordingly, several nations intend to reduce their dependence on fossil fuels, and particularly a wide range of western countries intend to reduce their reliance on the crude oil-producing OPEC countries $[1,19,25]$. Consequently, throughout the past decade, a notable transition towards renewable energies was incentivized by governments and multinational institutions $[2,30,84,85]$. Moreover, the impact of the transport sector on climate change and energy-related greenhouse gas (GHG) emissions has become a major aspect of political discussion throughout the past years $[1,4,84]$. Vehicles run by fossil fuels such as petroleum products are not only criticized for global GHG emissions but also for causing noise and local air pollution [2,19]. Several studies indicate that there are crucial environmental, consumer fuel-saving and macroeconomic benefits associated with alternative fuel vehicles, which are said to exceed the costs of electric vehicle incentives [86]. Moreover, in particular, EU-member states criticize the car-related petrol and diesel demand for having created a strong dependence on foreign energy sources. Thus, for geopolitical reasons, as well as due to the impact of the transport sector on climate change, several governments have started to provide significant public incentives to promote alternative fuel vehicles (AFVs). Throughout the past decade, several fiscal incentives were launched in Europe, Asia, North America and other regions to minimize the consumer's total cost of ownership (TCO) of AFVs with the aim to increase their competitiveness and market share [2,28]. However, the 
currently seen transition has caused significant economic costs and an important distortion of the market $[1,4,85]$.

The author evaluated the four main alternative fuel technologies which were most successful in Europe throughout the past years: hybrid electric (H-EVs) and plug-in hybrid electric (PH-EVs) vehicles and battery electric vehicles (B-EVs) and their "sub-category" of fuel cell electric vehicles (FC-EVs).

Public entities on the EU, national and municipal levels have tried to promote AFV technologies via different fiscal and legal supports. Public incentives for PEVs have differed significantly between the individual EU countries. Governments have promoted this market growth through a combination of financial incentives such as tax exemptions and direct subsidies as well as other incentives including free parking, but also by supporting the setup of charging infrastructure $[16,18,84]$. Public incentives for PEVs have differed significantly between the individual EU countries, while in several European markets, public subsidies and tax exemptions for PEVs have been quite substantial within recent years [5,6]. AFVs still face relevant barriers to adoption: barriers that are common to most new technologies, such as the lack of knowledge by potential adopters, a low consumer risk tolerance $[19,20]$ and high initial production costs [21]. By 2018, only comparably smaller Nordic countries such as Norway, Netherlands, Iceland and Sweden had a significant PEV sales growth occurred. In the Netherlands and Norway, sales volumes of AFVs have constantly been growing as simultaneously public incentives have compensated a significant portion of the AFVs' total vehicle cost [18]. It must be stated that in the absence of public incentives, PEVs have not been cost-competitive in any European market-despite the notable recent growth rate in PEVs sales.

The main challenge for our analysis of automotive sales (by using time series data) was the definition of the concrete correlation between specific independent variables and the dependent variable, as several intervening, moderating and control variables have also significantly changed throughout the analyzed period. For example, public incentives for AFVs might have developed in line with other relevant changes, such as an optimized EV recharging network, the optimization of the vehicle driving range and a general increase in consumer consciousness of environmental issues.

However, our analysis indicates that PEV sales grew most in those markets with the highest public incentives (Norway and Netherlands), whereas PEV sales in markets with low corresponding public incentives, such as Italy and Poland, had been almost irrelevant. Up until 2019, the market share of PEVs in most western automotive markets was significantly lower than what had previously been forecasted by most governments and several market analysts [52]. In 2020, with the rapid global spread of the COVID-19 pandemic, a significant economic crisis hit most economies, also aggravating the situation within the automotive sector. In order to "support" this sector, several governments implemented public incentive schemes, further incentivizing the purchase of PEVs. These intensified incentives were a crucial reason for the increase in PEV sales in the years 2020 and 2021. However, the economies of several countries (such as Spain) were significantly harmed by the effects of the COVID-19 crisis and the related restrictions and "lockdowns". Thus, it cannot be guaranteed that the recent level of public incentives to promote PEV technologies (including public support in establishing the needed recharging infrastructure) can be maintained to the same extent throughout the next years.

From the currently available AFV technologies, the author considers the FC-EV concept to be the most sustainable option, using hydrogen as an emission-free, environmentally neutral fuel. In this context, one must indicate that current full-electric vehicles (B-EVs) are also causing notable pollution, particularly as in most countries, the power generation necessary to fuel "green" B-EVs still depends on the use of fossil fuels. Moreover, today's PEVs are run by intricate lithium-based batteries, which are difficult to dispose of, containing toxic metals such as nickel, lead and copper, as well as toxic and flammable electrolytes [1,17]. In this context, the author expects that both electrofuels (fuels manufactured using renewable electricity), as well as fuel-cell electric vehicles (FC-EVs), could be inter- 
esting alternatives to the current "full-electric vehicle hype". One example of interesting new vehicle technology is the hydrogen-electric hybrid sports car "RG Nathalie". It is the first model produced by the new car manufacturer RG, founded by Roland Gumpert. The vehicle is equipped with a fuel cell that operates on methanol. Moreover, BMW is about to launch its SUV model "iX5 Hydrogen" with hydrogen fuel cell technology. However, due to the recent focus of public entities on promoting B-EVs in the passenger car industry, investments by automotive OEMs on FC-EV technologies have been limited-particularly by the European and US-American automotive OEMs. Thus, this narrowed focus has led to a reduced willingness of researchers and entrepreneurs to develop other, more effective vehicle fuel technologies [87].

The author agrees with Huerta de Soto that in today's real-world economies, one can detect several public interventions which hamper entrepreneurial freedom and competition while distorting the proper allocation of resources [88]. Thus, the currently seen incentives for AFVs must certainly be considered as one of these interventions. Based on Hayek, Kirzner and Huerta de Soto, the author highlighted the importance of free prices, crucial to properly allocate resources, as any governmental interventions on pricing via taxes and subsidies lead to a hampering market distortion $[23,51,79]$. Thus, free pricing is crucial to enable the market participants to communicate with each other via price signals, helping to solve the economic calculation problem [89]. Boettke explained that, when due to subsidies or other public interventions the official price of a product is below its actual free-market price, an excessive demand can be stimulated for that good [65]. Price controls distort the allocation of resources while hampering the free selection of goods by the consumers [89]. Correspondingly, any form of subsidies also distorts the market, enabling the users of a subsidized good (e.g., AFVs) to benefit from them without having to pay the actual free market price. In an economic system led by subsidies and other interventions, goods tend to become a political instrument, as their price, quality and production quantity will be influenced by public authorities. It is argued that without any form of government interventionism, the market could naturally readjust to the real demand situation [79]. Hayek had already properly stated that "the curious task of economics is to demonstrate to men how little they really know about what they imagine they can design." [90], arguing that central planning cannot properly anticipate market needs. On the other hand, Jenkin insists on the impact of economies of scale, which will help manufacturers to produce future AFVs at lower costs [74]. Concrete indications for increasing AFV sales volumes would then reassure car manufacturers to invest in larger production facilities for AFVs, leading to lower per-unit costs. Consequently, particularly for B-EVs, economies of scale will drive down total production costs of electric vehicles, enabling them to achieve much wider-scale adoption. As the market is in constant change, due to entrepreneurial creativity and changing subjective preferences of the market participants, it is impossible to predict which fuel type will "succeed" in the next decades, as completely new and more efficient engine technologies might soon be developed.

Despite the undisputable recent progress in regard to the acceptance of B-EV and PHEV technologies, the author agrees with Mises, Hayek and Huerta de Soto that a key fallacy in statist thinking has been to assume that conscious central planning by public entities would be more efficient than any unplanned "extended order" [78,79,82,90]. Accordingly, in line with Sowell, it is argued that the imperfections of the market must always be weighed against the imperfections of the government, as government interventions tend to make things worse [91]. From a geostrategic perspective, it is often highlighted that the transition of the European automotive industry towards electrification may reduce the EU's dependency on imported fossil fuels. However, it cannot be ignored that the most crucial raw materials for battery production, such as lithium, copper, nickel, cobalt, graphite and manganese, need to be mined from the ground. Additionally, these scarce resources can overwhelmingly be found in countries located outside of the European Union. In the case of China, its domestic lack of certain battery raw materials is more than compensated by its mid-stream supply chain dominance. China controls the processing of several critical 
minerals, such as lithium, cobalt and graphite. For example, China controls the cobalt refining industry in the "Democratic Republic of Congo" (which is the source of more than $60 \%$ of the global cobalt production), owning eight of the 14 largest Congolese cobalt mines [92]. Moreover, China has been significantly faster than the EU and the USA in building up a "lithium-ion-battery-to-electric-vehicle supply chain" by quickly increasing its number of "battery megafactories" to produce lithium-ion battery cells. Thus, at least for the running decade of the 2020s, China will continue to control the vast majority of the global lithium-ion production capacities. In 2021, a total of 122 of such lithium-ion battery megafactories was already operating globally, with another 78 factories confirmed to be finalized by 2030. Of this total of 200 megafactories (said to be operating by 2030), only 11 are to be located in the USA, 21 within continental Europe, but 148 corresponding factories are to be located in China. This dominance could likely enable China to lead the 21st century automotive and energy storage industries [93].

\section{Summary and Outlook}

It is expected that throughout the decade of the 2020s, public incentives for AFVs will be reduced. This will be possible due to mentioned economies of scale and the ongoing optimization of PEV technologies on the one hand, as well as due to "negative incentives" (such as further regulations, taxes and fees, or a complete ban) for traditional ICE vehicles on the other hand. Automotive manufacturers have used these recent years of strong fiscal interventionism to optimize their AFV models in regard to crucial aspects such as product quality, reliability, driving range and needed recharging times. Consequently, due to the seen public subsidies and other public interventions as well as due to the expected future economies of scale, it might be the case that by the early 2030's, most PH-EV and B-EV models will be price competitive without any further governmental support.

However, based on Hayek, the author concludes that it is neither morally nor economically appropriate to simply manipulate the market by implementing fiscal policies to increase the competitiveness of a specific product-even if, therefore, that product ultimately achieves price competitiveness caused by optimized economies of scale. The ends do not always justify the means, even if long-term price competitiveness of technologies can be achieved by initial short-term public interventionism to boost research and development investments into the corresponding new technology. The author indicated his concern that the implemented public incentives for AFVs are unsustainable, leading to market distortions which may cause a new, artificial market bubble. Thus, with the aim to "connect the dots", I intended to indicate the similarities between the public interventions (credit expansions, bailouts and scrappage programs) implemented in 2009-2010 to prevent the automotive industry from a further down-turn during the parallel subprime crisis, with the recent public incentives for AFVs. Accordingly, it is expected that the interventionist policies in the first decade of the 21st century were just as unsustainable for the automotive industry as the current market distortions to promote the current PEV technologies. The often-indicated argument that a transition of the European automotive industry towards electrification would reduce the EU's dependency on imported fossil fuels can be seen as valid, but must still be critically challenged: The most crucial raw materials for battery production need to be mined from the ground and can overwhelmingly be found in countries located outside of the European Union. Meanwhile, China has been able to establish a dominance in the processing of these raw materials, also holding the vast majority of the world's "battery megafactories" (to produce lithium-ion battery cells), for which China is expected to control large parts of the global lithium-ion production capacities. In addition, the recent shift from ICE vehicles towards PEVs creates a changing market environment in which new, mainly non-European, automotive manufacturers are expected to conquer a significant share in Europe's automotive market. 
Funding: This research received no external funding.

Institutional Review Board Statement: The study was conducted according to the guidelines of the Declaration of Helsinki.

Informed Consent Statement: Not applicable.

Acknowledgments: I would like to thank Jesus Huerta de Soto, Philipp Bagus, Miguel Angel Alonso and Roger Garrison for having raised my fascination for business cycle theories, as well as for monetary and fiscal policies. Moreover, I would like to express my gratitude to Aad van Mourik for his constructive non-Austrian criticism and contributions to the methodology and content of this paper.

Conflicts of Interest: The author has worked for a total of 15 years within the European automotive industry. Within this period, he worked for different automotive OEMs, such as Hyundai Motor Europe. A critical review of the general automotive industry was elaborated, without individually referring to specific OEMs, for which the author declares that no conflict of interest can be detected. The author is currently a Ph.D. student at Universidad Rey Juan Carlos (URJC Madrid), and this paper is an elaboration of one chapter of his planned Ph.D. thesis.

\section{References}

1. Hartmann, K. Die Grüne Lüge_Weltrettung als Profitables Geschäftsmodell; Random House Bertelsmann: Munich, Germany, 2018.

2. Brand, C.; Anable, J.; Tran, M. Accelerating the transformation to a low carbon passenger transport system. Transp. Res. Part A Policy Pract. 2013, 49, 132-148. [CrossRef]

3. ACEA. ACEA Position Paper on Electrically Chargeable Vehicles; Available from ACEA Database; 2020. Available online: https:/ / www.acea.be/uploads/publications/ACEA_on_ECVs.pdf (accessed on 11 December 2012).

4. Sinn, H.; Buchal, C.; Karl, H. Kohlemotoren, Windmotoren und Dieselmotoren: Was zeigt die CO2-Bilanz? Ifo Schnelld. 2019, 72, 40-54.

5. Drossinos, Y.; Levay, Z.; Thiel, C. The effect of fiscal incentives on market penetration of electric vehicles. Energy Policy 2017, 105, 524-533.

6. Skonhoft, A.; Holtsmark, B. The Norwegian support and subsidy policy of electric cars. Should it be adopted by other countries? Environ. Sci. Policy 2014, 42, 160-168.

7. Alonso Neira, M.; Bagus, P.; Rallo, J. The subprime crisis in the light of the Austrian business cycle theory: Credit expansion, decision errors and moral hazard. Rev. Econ. Mund. 2011, 28, 145-174.

8. Krugman, P. The Return of Depression Economics and the Crisis of 2008; W. W. Norton \& Company: New York, NY, USA, 2008.

9. Piketty, T. Capital in the Twenty-First Century; Harvard University Press: Cambridge, MA, USA, 2014.

10. Hülsmann, J. The Ethics of Money Production; Ludwig von Mises Institute: Auburn, Alabama, 2008.

11. Bagus, P.; Alonso, M.; Rallo, J. The First Global Financial Crisis of the 21st Century: Origins and Proposals of Reform. An Austrian Approach. Interdiscip. Econ. Bus. Law 2012, 2, 51-80.

12. Ikenson, D. Lasting Implications of the General Motors Bailout; Cato Publications; Cato Institute: Washington, DC, USA, 2011.

13. McMaken, R. How Long Will Cheap Debt Bail Out Automakers? Mises Wire. 2018. Available online: https://mises.org/wire/ how-long-will-cheap-debt-bail-out-automakers (accessed on 3 September 2020).

14. Nealer, R. Review of recent lifecycle assessments of energy and greenhouse gas emissions for electric vehicles. Renew. Energy Rep. 2015, 2, 66-73. [CrossRef]

15. Greene, D. Analyzing the transition to electric drive vehicles in the U.S. Futures 2014, 58, 34-52. [CrossRef]

16. Lutsey, N. Supporting the Electric Vehicle Market in U.S. Cities; Retrieved from ICCT; The International Council on Clean Transportation: Washington, DC, USA, 2015.

17. Carlucci, F.; Cirà, A.; Lanza, G. Hybrid Electric Vehicles: Some Theoretical Considerations on Consumption Behaviour. Sustainability 2018, 10, 1302. [CrossRef]

18. Mock, P.; Yang, Z. Driving Electrification: A Global Comparison of Fiscal Policy for Electric Vehicles; Retrieved from ICCT; The International Council on Clean Transportation: Washington, DC, USA, 2014.

19. Jaffe, B.; Stavins, R. Energy-efficiency investments and public policy. Energy J. 1994, 15, 43-65. [CrossRef]

20. Stoneman, P.; Diederen, P. Technology diffusion and public policy. Econ. J. 1994, 104, 918-930. [CrossRef]

21. Epple, D.; Darr, E.; Argote, L. The acquisition, transfer, and depreciation of knowledge in service organizations: Productivity in franchises. Manag. Sci. 1995, 41, 1750-1762.

22. Hayek, F.A. Profits, Interest, and Investment; Routledge: London, UK, 1939.

23. Kirzner, I. Competition and Entrepreneurship; The University of Chicago Press: London, UK, 1973.

24. Egbue, O.; Long, S. Barriers to widespread adoption of electric vehicles: An analysis of consumer attitudes and perceptions. Energy Policy 2012, 48, 717-729. [CrossRef]

25. Walther, G.; Wansart, J.; Kieckhäfer, K.; Schnieder, E.; Spengler, T. Impact assessment in the automotive industry—mandatory market introduction of alternative powertrain technologies. Syst. Dyn. Transp. 2010, 26, 239-261. [CrossRef] 
26. Orwell, G. Nineteen Eighty-Four-1984; Secker \& Warburg: London, UK, 1949; p. 229.

27. Canes, M. Economics of hybrid electric vehicles. IAEE Newsl. 2003, 9, 13-17.

28. Axsen, J.; Goldberg, S.; Bailey, J. How might potential future plug-in electric vehicle buyers differ from current "Pioneer" owners? Transp. Res. Part D Transp. Environ. 2015, 47, 357-370. [CrossRef]

29. Lutsey, N. Transition to a Global Zero-Emission Vehicle Fleet: A Collaborative Agenda for Governments; Retrieved from ICCT; The International Council on Clean Transportation: Washington, DC, USA, 2015.

30. Lane, B.; Potter, S. The adoption of cleaner vehicles in the UK: Exploring the consumer attitude-action gap. J. Clean. Prod. 2007, 15, 1085-1092. [CrossRef]

31. Tran, M.; Banister, D.; Bishop, J.; McCulloch, M. Simulating early adoption of alternative fuel vehicles for sustainability. Technol. Forecast. Soc. Chang. 2013, 80, 865-875. [CrossRef]

32. Zhang, X.; Bai, X.; Shang, S. Is subsidized electric vehicles adoption sustainable: Consumers' perceptions and motivation toward incentive policies, environmental benefits, and risks. J. Clean. Prod. 2018, 192, 71-79. [CrossRef]

33. Wu, G.; Inderbitzin, A.; Bening, C. Total cost of ownership of electric vehicles compared to conventional vehicles: A probabilistic analysis and projection across market segments. Energy Policy 2015, 80, 196-214. [CrossRef]

34. Bjerkan, K.Y.; Norbech, T. Incentives for promoting Battery Electric Vehicle (B-EV) adoption in Norway. Transp. Res. Part D Transp. Environ. 2016, 43, 169-180. [CrossRef]

35. Figenbaum, E.; Fearnley, N.; Pfaffenbichler, P.; Hjorthol, R.; Kolbenstvedt, M.; Jellinek, R. Increasing the competitiveness of e-vehicles in Europe. Eur. Transp. Res. Rev. 2015, 7, 1-14. [CrossRef]

36. Carley, S.; Krause, R.; Lane, B.; Graham, J. Intent to purchase a plug-in electric vehicle: A survey of early impressions in large US cities. Transp. Res. Part D Transp. Environ. 2013, 18, 39-45. [CrossRef]

37. Brand, C.; Cluzel, C.; Anable, J. Modeling the uptake of plug-in vehicles in a heterogeneous car market using a consumer segmentation approach. Transp. Res. Part A Policy Pract. 2017, 97, 121-136. [CrossRef]

38. Lomborg, B. False Alarm: How Climate Change Panic Costs Us Trillions, Hurts the Poor, and Fails to Fix the Planet; Basic Books: New York, NY, USA, 2020.

39. Rogers, E. Diffusion of Innovations; Free Press: New York, NY, USA, 2003.

40. Ajzen, I. From Intentions to Action: A Theory of Planned Behaviour; Springer: New York, NY, USA, 1985.

41. Struben, J.; Sterman, J. Transition challenges for alternative fuel vehicle and transportation systems. Environ. Plan. B Plan. Des. 2006, 35, 1070-1097. [CrossRef]

42. Mises, L. Theory and History: An Interpretation of Social and Economic Evolution; Yale University Press: New Haven, CT, USA, 1957.

43. Dudenhöffer, F. Autoindustrie—auf dem richtigen Weg? Wirtsch.—Z. Wirtsch. 2019, 7, 451-469.

44. Dudenhöffer, F. Wer Kriegt die Kurve? Zeitenwende in der Autoindustrie; Campus Verlag: Frankfurt, Germany, 2016.

45. Sovacool, B.K.; Hirsh, R.F. Beyond batteries: An examination of the benefits and barriers to plug-in hybrid electric vehicles (PH-EVs) and a vehicle-to-grid (V2G) transition. Energy Policy 2009, 37, 1095-1103. [CrossRef]

46. Amblard, M. How Nio, Byton, Lucid, Rivian and Others Emulate Tesla. Available at Medium Database. 2018. Available online: https:/ / medium.com/@mamblard75/how-nio-byton-lucid-rivian-and-others-emulate-tesla-42e44a6f82b (accessed on 14 September 2020).

47. Lieven, T.; Mühlmeier, S.; Henkel, S.; Waller, J.F. Who will buy electric cars? An empirical study in Germany. Transp. Res. Part D Transp. Environ. 2011, 16, 236-243. [CrossRef]

48. Jansson, J. Adoption of alternative fuel vehicles: Influence from neighbors, family and co-workers. Transp. Environ. 2017, 54, 61-73. [CrossRef]

49. Carrasco, E.; Martín, M.L.; Díaz, E. Análisis y Perspectiva de la Situación Medioambiental del Sector de Automoción en Espana; Dykinson: Madrid, Spain, 2009.

50. Friedman, M. Price Theory; Routledge: New York, NY, USA, 1962.

51. Hayek, F.A. Prices and Production; Routledge: London, UK, 1931.

52. IEA. Electric Vehicle: Tracking Report_June 2020; International Energy Agency: Paris, France, 2020; Available online: https: / / www.iea.org/reports/electric-vehicles (accessed on 30 December 2020).

53. Campell, A.; Ryley, T.; Thring, R. Identifying the early adopters of alternative fuel vehicles: A case study of Birmingham. Transp. Res. Part A Policy Pract. 2012, 46, 1318-1327. [CrossRef]

54. Axsen, J.; Kurani, K. Social influence, consumer behavior and low-carbon energy transitions. Annu. Rev. Environ. Resour. 2012, 37, 311-340. [CrossRef]

55. Jensen, A.; Cherchi, E.; Lindhard-Mabit, S. On the stability of preferences and attitudes before and after experiencing an electric vehicle. Transp. Res. Part D Transp. Environ. 2013, 25, 24-32. [CrossRef]

56. Harrison, G.; Thiel, C. An exploratory policy analysis of electric vehicle sales competition and sensitivity to infrastructure in Europe. Technol. Forecast. Soc. Chang. 2017, 114, 165-178. [CrossRef]

57. Tidd, J.; Bessant, J.; Pavitt, K. Managing Innovation: Integrating Technological, Market and Organisational Change; John Wiley and Sons Ltd.: Chichester, UK, 2005.

58. Ajzen, I. The theory of planned behavior. Organ. Behav. Hum. Decis. Process. 1991, 50, 179-211. [CrossRef]

59. Lebeau, K.; Lebeau, P.; Macharis, C.; Van Mierlo, J. How expensive are electric vehicles? A total cost of ownership analysis. World Electr. Veh. J. 2013, 6, 996-1007. [CrossRef] 
60. Dijk, M.; Kemp, R. The emergence of an electric mobility trajectory. Energy Policy 2013, 52, 135-145. [CrossRef]

61. Windrum, P.; Birchenhall, C. Structural changes in the presence of network externalities. J. Evol. Econ. 2005, 15, 123-148. [CrossRef]

62. Rezvani, Z.; Bodin, J. Advances in consumer electric vehicle adoption research: A review and research agenda. Transp. Res. Part D Transp. Environ. 2015, 34, 122-136. [CrossRef]

63. European Commission. $\mathrm{CO}_{2}$ Emission Performance Standards for Cars and Vans. In EU Climate Action \& Green Deal: Transport. 2014. Available online: https:/ / ec.europa.eu/clima/policies/transport/vehicles/regulation_en (accessed on 15 October 2020).

64. ICCT. International Council on Clean Transportation (ICCT) White Paper. Retrieved from Green Car Congress. 2014. Available online: https:/ / www.greencarcongress.com/2014/05/20140506-icctev.html (accessed on 30 December 2020).

65. Boettke, P.J. Calculation and Coordination: Essays on Socialism and Transitional Political Economy; Routledge: New York, NY, USA, 2001.

66. Menger, C. Principles of Economics; Free Press: New York, NY, USA; Glencoe, UK, 1951; p. 121.

67. McKinsey. Electric Vehicles in Europe: Gearing up for a New Phase? McKinsey \& Company: New York, NY, USA, 2014.

68. Asthana, A.; Taylor, M. Britain to Ban Sale of All Diesel and Petrol Cars and Vans from 2040. Retrieved from The Guardian. 2017. Available online: https:/ / amp.theguardian.com/politics/2017/jul/25/britain-to-ban-sale-of-all-diesel-and-petrol-cars-andvans-from-2040 (accessed on 30 December 2020).

69. Jacobs, F. Norway to Ban New Fossil-Fuel Cars from 2025. Fleet Europe. 2016. Available online: https://www.fleeteurope.com/ en / safety / / article/norway-ban-new-fossil-fuel-cars-2025? a =FJA05\&t $\% 5 B 0 \% 5 D=$ Tesla\&t $\% 5 B 1 \% 5 D=C O 2 \& t \% 5 B 2 \% 5 D=F u e l \&$ curl=1 (accessed on 30 December 2020).

70. Pelegov, D.; Pontes, J. Main Drivers of Battery Industry Changes. Batteries 2018, 4, 65. [CrossRef]

71. Hertzke, P.; Müller, N.; Schenk, S.; Wu, T. The Global Electric-Vehicle Market Is Amped up and on the Rise. McKinsey Cent. Future Mobil. Automot. Assem. Insights 2018. Available online: https://www.mckinsey.com/industries/automotive-and-assembly/ourinsights (accessed on 10 December 2020).

72. Dataforce. Dataforce Marktdaten: Neuzulassungen Nach Antriebsarten. 2020. Available online: https://www.dataforce.de/pkwneuzulassungen-weltweit-2/ (accessed on 1 December 2020).

73. McDonald, S.; Bailey, R. Bloomberg NEF EVO Report 2020. Electric Vehicle Outlook. 2020. Available online: https://about.bnef. com/electric-vehicle-outlook/ (accessed on 1 December 2020).

74. Jenkins, J. The changing economics of electric vehicles. Rapidly falling costs of battery packs for EVs. Nat. Clim. Chang. 2015, 5, 329-332.

75. Story, J. Learning Curves, Economies of Scale, and Strategic Marketing; Primal Strategy Publications: Houston, TX, USA, 2016.

76. Büttner, J. Die chemische Formel vieler Anlegerträume lautet H2. Smart Investig. 2020, 9, 6-11.

77. Reimers, P. Fiat Lux \& Crony Capitalism. The Impact of Monetary and Fiscal Policies on the Automobile Industry in USA and Europe from 2001 to 2010. Procesos Merc. 2018, 15, 107-163.

78. Mises, L. Socialism: An Economic and Sociological Analysis; Liberty Fund: Indianapolis, IN, USA, $1951 ;$ p. 121.

79. De Soto, J.H. Socialism, Economic Calculation and Entrepreneurship; Edward Elgar Publishing: Cheltenham, UK, 2005.

80. Reimers, P. Spontaneous Order versus Central Planning: A Comparison of Michael Polanyi \& F.A. von Hayek. Procesos Merc. 2020, 17, 173-216.

81. Friedman, M. Interview with Richard Heffner of Rutgers University on 'Open Mind'. 1975. Available online: https://www. youtube.com/watch?time_continue=385\&v=JfdRpyfEmBE\&feature=emb_title (accessed on 2 September 2020).

82. Echarte Fernández, M.A.; Náñez Alonso, S.; Jorge-Vázquez, J.; Reier Forradellas, R.F. Central Banks' Monetary Policy in the Face of the COVID-19 Economic Crisis: Monetary Stimulus and the Emergence of CBDCs. Sustainability 2021, 13, 4242. [CrossRef]

83. Kirzner, I. Market Theory and the Price System; D. Van Nostrand Co., Inc.: Princeton, NJ, USA, 1963.

84. Gass, M.; Schmidt, J.; Schmid, E. Analysis of alternative policy instruments to promote electric vehicles in Austria. Renew. Energy 2013, 61, 96-101. [CrossRef]

85. Wang, W.H.; Moreno-Casas, V.; de Soto, J.H. A free-market environmentalist transition toward renewable energy: The cases of Germany, Denmark, and the United Kingdom. Energies 2021, 14, 4659. [CrossRef]

86. Greene, D.L.; Park, S.; Liu, C. Transitioning to Electric Drive Vehicles; Retrieved from ICCT; The International Council on Clean Transportation: Washington, DC, USA, 2014.

87. Zoellter, J. Flirt Mit Nathalie. Frankfurter Allgemeine. FAZ.Net. 2020. Available online: https://www.faz.net/aktuell/technikmotor/elektromobilitaet/elektroauto-von-gumpert-der-neue-sportwagen-nathalie-17042595.html (accessed on 20 June 2021).

88. De Soto, J.H. Crisis Financiera y Recesión Económica; URJC: Madrid, Spain, 2009.

89. Espinosa, V.; Wang, W.H.; Zhu, H. Israel Kirzner on dynamic efficiency and economic development. Procesos Merc. 2020, 17, 283-310.

90. Hayek, F.A. The Fatal Conceit: The Errors of Socialism; Routledge: London, UK, 1990; p. 76.

91. Sowell, T. Basic Economics: A Common Sense Guide to the Economy; Basic Books: Philadelphia, PA, USA, 2015.

92. Moores, S. Global Battery Arms Race: 200 Gigafactories, China Leads. Benchmark Mineral Intelligence. Benchmark Quarterly (25)1. 2021. Available online: https://www.benchmarkminerals.com/membership/global-battery-arms-race-200-gigafactorieschina-leads-2/ (accessed on 8 August 2021).

93. Todd, F. China, Cobalt and the Congo: Why Xi Jinping Is Winning the ‘Batteries Arms Race'. NS Energy. Analysis Section. 2019. Available online: https:/ / www.nsenergybusiness.com/features/china-cobalt-congo-batteries/ (accessed on 20 August 2021). 